\title{
Article \\ Reconstructing the Variscan Terranes in the Alpine Basement: Facts and Arguments for an Alpidic Orocline
}

\author{
Michel Faure ${ }^{1, *(1)}$ and Jacky Ferrière ${ }^{2}$ \\ 1 Institut des Sciences de la Terre d'Orléans (ISTO), UMR 7327-CNRS/Université d'Orléans/BRGM, \\ 1A Rue de la Férollerie, CEDEX 2, 45071 Orléans, France \\ 2 Laboratoire d'Océanologie et de Géosciences (LOG), UMR 8187, \\ Université Lille/CNRS/Université du Littoral Côte d'Opale, 59000 Lille, France; jacky.ferriere@univ-lille.fr \\ * Correspondence: michel.faure@univ-orleans.fr
}

check for

updates

Citation: Faure, M.; Ferrière, J. Reconstructing the Variscan Terranes in the Alpine Basement: Facts and Arguments for an Alpidic Orocline. Geosciences 2022, 12, 65. https:// doi.org/10.3390/geosciences12020065

Academic Editors: Rodolfo Carosi,

Mario da Costa Campos Neto, Haakon Fossen, Chiara Montomoli, Matteo Simonetti, Olivier Lacombe and Jesus Martinez-Frias

Received: 12 December 2021

Accepted: 25 January 2022

Published: 30 January 2022

Publisher's Note: MDPI stays neutral with regard to jurisdictional claims in published maps and institutional affiliations.

Copyright: (C) 2022 by the authors. Licensee MDPI, Basel, Switzerland. This article is an open access article distributed under the terms and conditions of the Creative Commons Attribution (CC BY) license (https:// creativecommons.org/licenses/by/ $4.0 /)$.

\begin{abstract}
The existence of pieces of the Variscan belt in the Alpine basement has been acknowledged for a long time but the correlation of these massifs to the litho-tectonic domains established in Western Europa outside the Alpine chain is still disputed. Due to their ubiquitous character, the abundant late Variscan migmatites and granites are useless to reconstruct the Variscan architecture in the Alpine basement. Ophiolitic sutures, high- and low-grade metamorphic units, and foreland basins provide a preliminary reconstruction of the Variscan orogen exposed in the Alpine basement. The longitudinal extension of the Armorican and Saxo-Thuringian microcontinents between Laurussia and Gondwana is proposed independently of the Intra-alpine and Galatian terranes. The litho-tectonic units of the Corsica-Sardinia segment are correlated to the Moldanubian, Armorican and Saxo-Thuringian Domains. In the Alpine Helvetic and Penninic Domains, the Chamrousse ophiolites are ascribed to the Tepla-Le Conquet suture, whereas the Lepontine, and Stubach ophiolites represent the Rheic suture. The south-directed nappe stack of the South Alpine Domain is similar to the Moldanubian French Massif Central. In the Austroalpine nappe stack, the Ritting ophiolites separate Saxo-Thuringia and Armorica continental blocks. Disentangling the Variscan belt in the Alpine basement suggests a concave-to-the-East arcuate structure called here the Variscan Alpidic orocline.
\end{abstract}

Keywords: Variscan belt; Alpine basement; orocline; Paleozoic ophiolites; Western Alps; South Alpine; Austroalpine

\section{Introduction}

Between northern Europa, characterized by the Precambrian Baltic shield, and the Early Paleozoic Caledonian belt, and southern Europa characterized by the Cenozoic Alpine orogenic belt, and the late-orogenic Mediterranean basins, Medio Europa is the place of the Paleozoic Variscan belt that forms the backbone of the continent (Figure 1). From Iberia to Bohemia, the Variscan belt has been subdivided into four domains, namely Rheno-Hercynian, Saxo-Thuringian, Armorican, and Moldanubian (Figure 2, see Section 2 below for details). In southern and eastern Europa, the Variscan orogen has been variously reworked during the Alpine orogeny either by tectono-thermal overprints or by rigid block rotations and translations. Therefore, the structure of the Variscan belt exposed in the Alpine basement is difficult to decipher.

The already proposed geodynamic reconstructions can be gathered into two groups. The first one proposes several east-west trending terranes in which the Alpine Variscan massifs belong to the "Hunic", "Intra-Alpine", and "Galatian" terranes assemblage located between the Rheic and Paleotethys oceans to the north and south, respectively (e.g., [1-6] and enclosed references). The links between these terranes and the four Variscan domains devoid of any important Alpine overprint outside of the Alpine belt are seldom considered (Figure 2). Another group of thought interprets the Western Alps' external crystalline 
basement as pieces of the Moldanubian Domain (see Section 2 below) offset by the dextral East Variscan Shear Zone from the Bohemian massif [7-13]. In these models, an oroclinal bending, similar to the Iberia-Armorica one is suggested but not really discussed $[1,9,10]$. Although in a given area, it is often possible to recognize the remnants of ductile pre-alpine synmetamorphic deformation phases and late- to post-orogenic events, it is generally more delicate to replace these elements in the bulk architecture of the Variscan orogen.

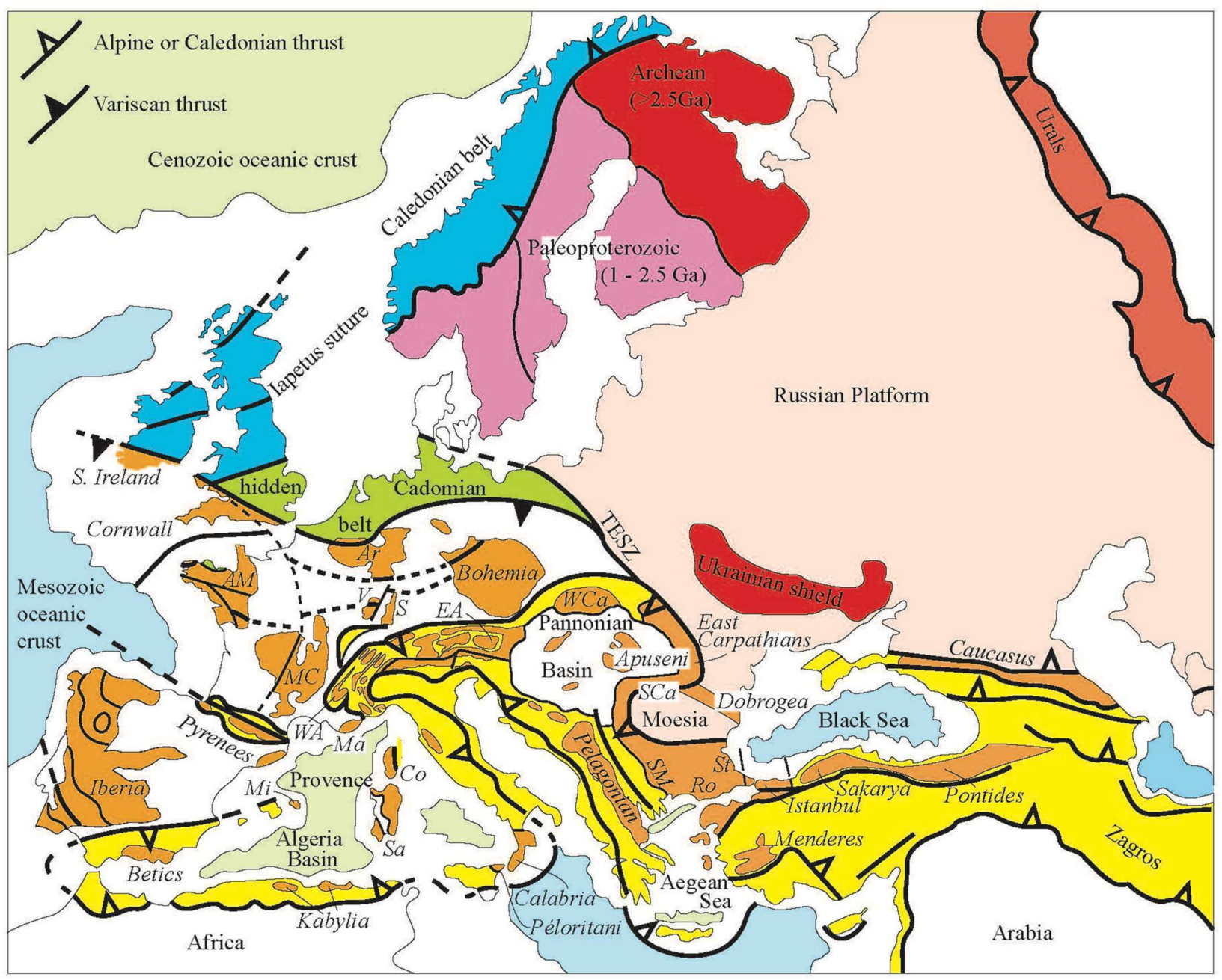

Figure 1. Tectonic map of Europa. The Variscan belt (in orange) occupies the medial part of the continent between the Early Paleozoic Caledonian belt (in blue) on northern Europa and the Cenozoic Alpine belt (in yellow) of southern Europa. The continuity of the Alpine belt is disrupted by the opening of the Neogene back-arc basins (in pale green). The Neoproterozoic Cadomian belt is hidden by younger formations or reworked in the Variscan belt. WA: Western Alps, EA: Eastern Alps, Ar: Ardenne, Co: Corsica, Ma: Maures, AM: Armorican Massif, MC: Massif Central, Mi: Minorca, Ro: Rhodope, S: Schwarzwald, Sa: Sardinia, SCa: South Carpathians, SM: Serbo-Macedonian, St: Strandja, TESZ: Trans-European Suture Zone. 


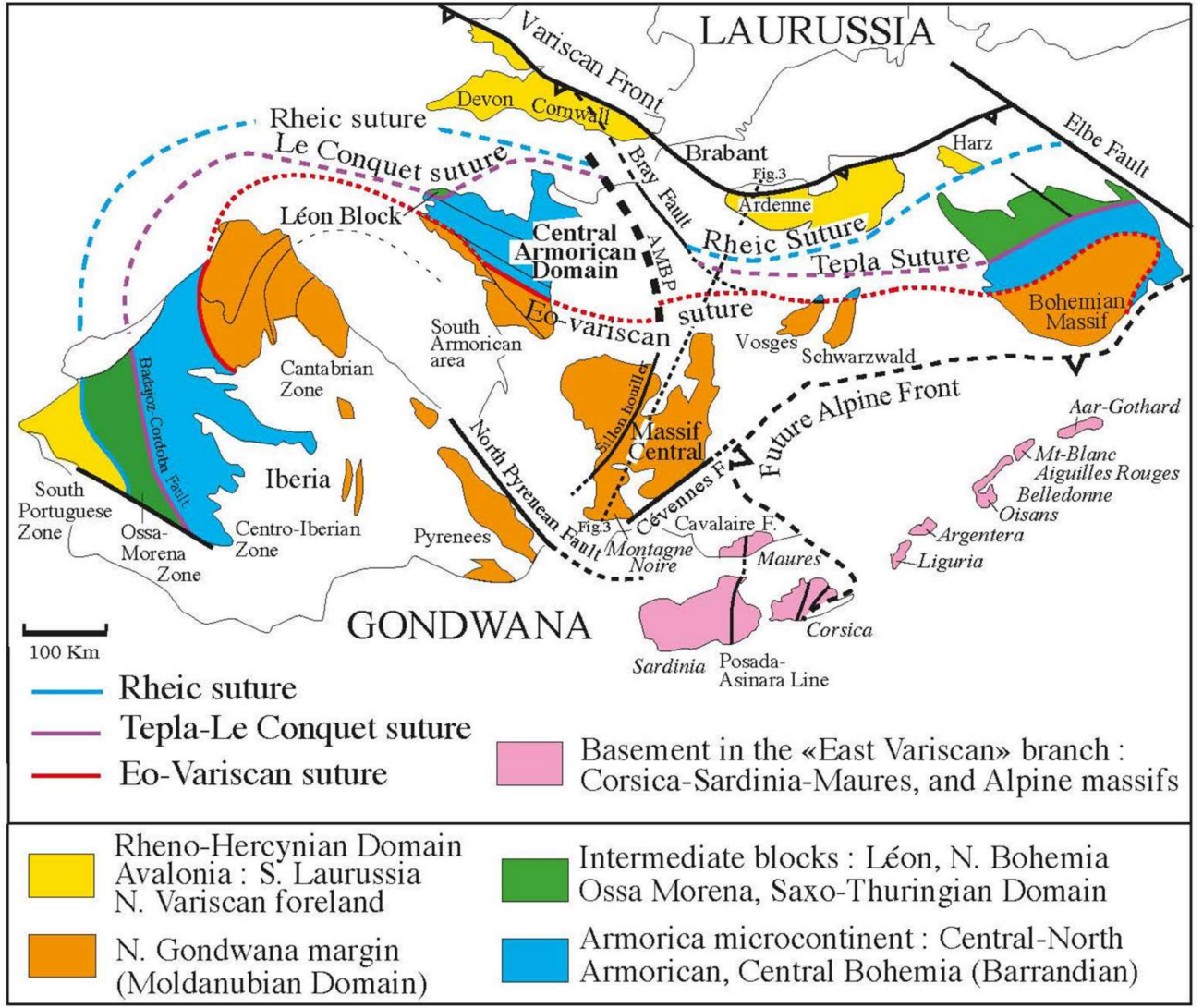

Figure 2. Tectonic map of the Variscan belt of Western Europe. Three ophiolitic sutures, namely Rheic, Le Conquet-Tepla, and Eo-variscan, separate several continental masses. From North to South, they are Laurussia (Avalonia) represented by the Rheno-Hercynian Domain, Saxo-Thuringian Domain, Armorica, and Moldanubian Domain corresponding to the North Gondwana margin. The Eastern Variscan branch is represented by the Corsica-Sardinia-Maures massifs, and Alpine basement massifs. Note that Iberia, Corsica-Sardinia, and Alpine External massifs are qualitatively restored to their Permian position before the opening of the Biscay bay and the Provence-Algeria basins.

This paper aims at presenting the structural and metamorphic data acquired in the Variscan massifs involved in the Alpine orogen in the western Alps, southern Alps, and Austroalpine areas. Though still speculative, the possible correlations of these massifs with the Variscan domains devoid of important Alpine overprint settled outside the Alpine belt are proposed. In the following, the focus will be placed on the reconstruction of the Variscan architecture, recognition of ophiolitic sutures, nappe transport direction, and foreland basins. Granite plutons and migmatites are important elements of the Variscan orogen. Nevertheless, they are not first-order criteria to decipher the Variscan zonation, since petrologically, geochemically, and chronologically similar migmatites and granites can be observed in various domains. For instance, this is the case in the French Variscan segment, where there is no significant difference between the widespread migmatites and granitic plutons observed in the Moldanubian, Armorican, and Saxo-Thuringian Domains. Thus, these rocks that formed during the late-orogenic stages will not be considered since their ubiquitous character does not help to reconstruct the early Variscan architecture.

\section{An Outline of the "Main" Variscan Belt}

The bulk zonation of the Variscan belt, first established in Central Europa by Kossmatt in 1927 [14] see [15] for English translation, is well acknowledged in Bohemia, Germany, France, SW England, and Iberia (e.g., [16-23] and enclosed references). For example, along a N-S profile from SW England-Belgium to the Mediterranean coast, the following four litho-tectonic domains are recognized (Figures 2 and 3). 
(i) The Rheno-Hercynian Domain exposed in Devon-Cornwall, and Ardenne represents the northern fold-and-thrust belt developed northward up to the Variscan front in the Avalonian part of Laurussia.

(ii) The Saxo-Thuringian Domain, represented in NW Brittany by the Léon block, is a microcontinent rifted from Gondwana in the Ordovician and rewelded to it in the Carboniferous.

(iii) The Armorican Domain, well exposed in Central Brittany and Normandy, is another microcontinent separated from Gondwana in Early Ordovician, and rewelded to it during the Variscan orogeny. It is worth noting that both in the Saxo-Thuringian and Armorican domains, the Paleozoic formations unconformably overlie deformed Ediacaran rocks ascribed to the Cadomian orogen $[7,18,19]$.

(iv) The Moldanubian Domain is the most metamorphic part of the Variscan orogen formed by a stack of ductile nappes. In France, it is well developed in the southern part of the Armorican Massif, the entire Massif Central, and the Pyrenees. In Massif Central and southern part of the Armorican Massif, the well-acknowledged stack of nappes evolves from highly metamorphic rocks to sedimentary formations from North to South, respectively. From top to bottom, there are: (a) the Neoproterozoic basement nappe, (b) the eo-Variscan ophiolite nappe, (c) the Upper Gneiss Unit with high-pressure rocks, (d) the MP/MT Lower Gneiss Unit, (e) the LP/LT Paraautochthonous Unit, (f) the Fold-and-Thrust belt, and (g) the southern foreland basin (Figure 3). A complete description of the Moldanubian nappe stack is beyond the scope of this paper (for details on the Massif Central, and South Armorican areas, see $[18,22,24-27])$.

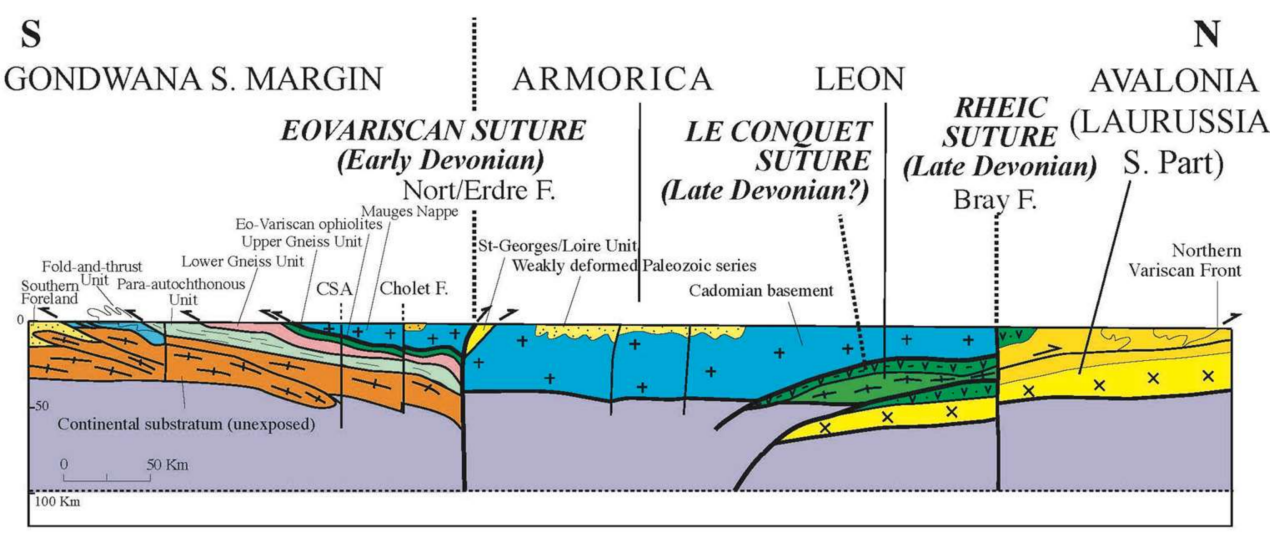

Figure 3. Simplified crustal-scale cross-section of the Variscan orogen in the French segment (located in Figure 2, modified from [16]). The southern part of the belt is related to the Early to Middle Devonian eo-Variscan collision of the North Gondwana margin and Armorica. Note that in Figure 2 the detail of the nappe stack is not represented. To the North, the Rheic suture separates the Avalonia (i.e., the southern margin of Laurussia) and the Léon microcontinent belonging to the Saxo-Thuringian domain. The Le Conquet (or Tepla) suture separates the Léon microcontinent and Armorica. For clarity, the late-orogenic plutons and migmatitic massifs have been omitted.

It is worth to note that the Moldanubian Domain experienced a diachronic tectonic evolution. In the northern part of the Moldanubian Domain, the Upper Gneiss and Lower Gneiss metamorphic units were unconformably covered by undeformed and nonmetamorphic, Early Visean shallow-water limestone deposits, and a volcanic-sedimentary formation, paleontologically and radiometrically dated at ca 335-330 Ma, called "Tufs anthracifères" (e.g., [26]). This formation is an important time-marker for demonstrating the existence of pre-Carboniferous tectonic events in the French Moldanubian Domain. On the contrary, the southern part of the Moldanubian Domain (Montagne Noire, E. Pyrenees) is represented by a fold-and-thrust belt and a Visean-Serpukhovian foreland basin [28-31]. From a paleogeographic point of view, the Moldanubian Domain belongs to the north 
Gondwana margin. The Mediterranean Cenozoic tectonics responsible for the opening of the Provence-Algeria basin (Figure 1), and the counterclockwise rotation of the CorsicaSardinia block destroyed the South Variscan front [32].

These four domains are separated by three ophiolitic sutures, but a complete ophiolitic succession is never exposed due to reworking by subsequent tectonic phases, partly by strike-slip faulting. From North to South, the Rheic, Le Conquet-Tepla, and eo-Variscan sutures are recognized (Figures 2 and 3). They represent the relics of three oceanic basins opened during the Late Cambrian to Early Ordovician rifting. The basins' closure occurred in Late Devonian-Early Carboniferous (Famennian-Tournaisian) for the Rheic ocean, and probably the Tepla-Le Conquet one. The closure time of the eo-Variscan suture that separates the Armorica and Moldanubian domains is alternatively considered as Late SilurianEarly Devonian (ca 420-400 Ma) or Late Devonian-Early Carboniferous (ca 360-350 Ma), (see $[18,19,22,24,25,33])$. Due to similar Cambrian and Ordovician fauna, some authors even denied the existence of an oceanic domain between Armorica and Gondwana [34]. However, the similarity in faunal distribution can also be explained by the small size of the oceanic basin separating the two domains that allowed important faunal exchanges on both sides of the basin. The Upper Gneiss Unit of the Moldanubian domain contains a peculiar assemblage of felsic gneiss and amphibolite, recognized since [35] as the "leptynite-amphibolite complex" (LAC). This formation that also includes mafic eclogites and serpentinites has sometimes been considered as an ophiolitic suite. However, it is now interpreted as a piece of an extended continental crust injected by felsic and mafic magmas (e.g., $[18,27])$. Such a bimodal magmatism represents an ocean-continent transition coeval with the development of a passive continental margin. The LAC is widespread in the Moldanubian Domain, but also exists in the Saxo-Thuringian Domain and thus cannot be taken as an unequivocal criteria for one peculiar domain.

As recognized for a long period of time, the Variscan belt appears as a bi-vergent orogen (Figure 3) developed all along the Paleozoic, starting with an Early Ordovician pre-orogenic rifting that separated several microcontinents from Gondwana to an Early Carboniferous (Tournaisian) collision that led to the final assembly of the Laurussia and Gondwana continents with intervening ribbon-like blocks or microcontinents. The Variscan continental collision was mainly accommodated by a southward subduction (in the present coordinates), followed by the development of Visean to Pensylvannian intracontinental fold-and-thrust belts on both sides of the orogen, and by late- to post-orogenic extensional tectonics coeval with a huge crustal melting represented by numerous gneiss-migmatitic domes and granitic plutons $[16,22,26]$. As mentioned above, granitic plutons and migmatitic domes are widespread in the Moldanubian, Armorican, and Saxo-Thuringian domains. Thus these rocks do not represent a specific signature for a given domain. In the following, they will not be used for the proposed correlations.

Furthermore, in SE France and Italy, the Variscan rocks exposed in Corsica, Sardinia, and Maures massifs, and in the Alpine basement, crystalline massifs define an East Variscan branch (Figure 2). The petrographic, geochemical, geochronological and structural studies of the various tectonic, metamorphic, and magmatic events experienced by these massifs are provided in numerous articles (e.g., [2,9,36-40] and enclosed references). However, in this "East Variscan branch", it becomes more challenging to define the litho-tectonic units, and to reconstruct the bulk architecture of the Variscan edifice, due to the Alpine overprint.

\section{The East Variscan Branch of Western Europe}

This section deals with the possible correlations between the litho-tectonic elements recognized in the East Variscan Branch and those established in the Main Variscan Belt presented in Section 2. Thus the Late Variscan structures such as the Posada-Asinara or Cavalaire fault (Figure 4), as well as the Late Carboniferous intrusions, and the Permian or younger tectonic events that deformed the main foliation, are not considered here. 


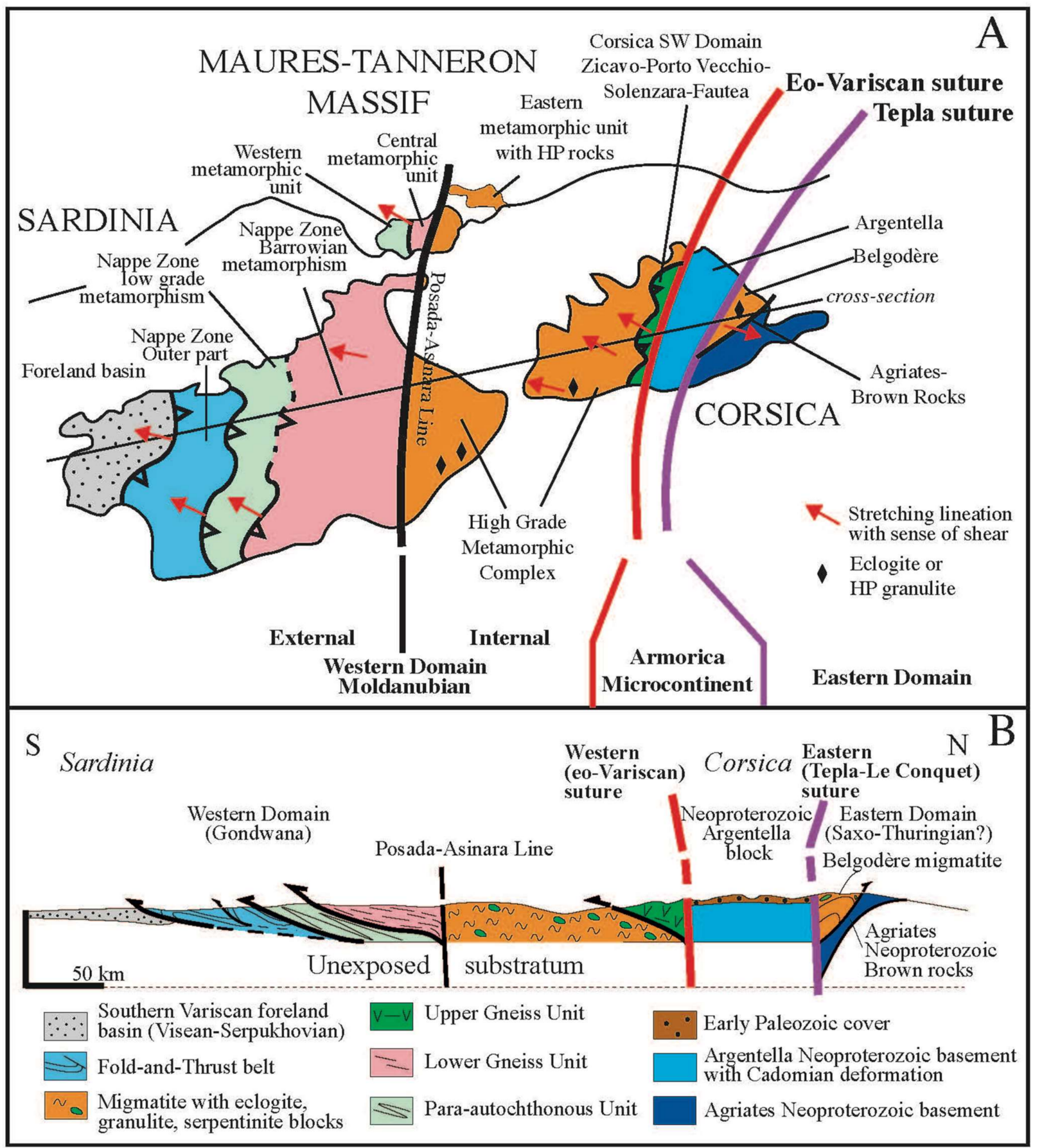

Figure 4. The Sardinia-Corsica segment. (A): Tectonic correlation between the Sardinia, Corsica, and Maures massifs restored to their pre-Cenozoic position. The North-South zonation (in the present position), is similar to that recognized in the French Massif Central, and the Maures Massif. In NW Corsica, the Argentella area, characterized by a Neoproterozoic basement and its Paleozoic cover, is correlated with the Armorican Domain. In the Belgodère and Agriates areas, the top-tothe-east shearing suggests that they belong to the Saxo-Thuringian Domain. The granitic intrusions are not shown. (B): schematic cross-section of the nappe stack in the Sardinia-Corsica segment (in its present orientation), and possible correlations with the main units recognized in the French Massif Central. The southern part of the section is similar to the Moldanubian Domain, whereas the northwestern (Argentella), and Central Corsica (Belgodère-Agriates) parts are correlated with Armorica and Saxo-Thuringian Domains, respectively. 


\subsection{The Corsica-Sardinia-Maures Segment}

It is well acknowledged that the Corsica and Sardinia islands experienced a ca $30-45^{\circ}$ anticlockwise rotation during the opening of the Provence-Algeria basin in OligoceneMiocene (e.g., [23,32,41,42]). The restoration of the initial position of the Corsica-Sardinia block against the Maures-Tanneron massif documents a reasonable correlation of this part of the East Variscan branch with the main Variscan belt exposed in the Massif Central and Pyrenees (Figure 4).

The Visean-Serpukhovian foreland basin of SW Sardinia (Figure 4) is lithologically, stratigraphically, and structurally similar to the ones developed in Montagne Noire (S. Massif Central), Eastern Pyrenees, and Minorca (e.g., [29,30,37,43]). The outer non metamorphic part and low-grade metamorphic units of the southern part of the Nappe zone of Sardinia can be correlated with the Fold-and-Thrust belt, and the Para-autochthonous units of Massif Central, respectively. The barrovian metamorphic unit in the northern part of the Nappe zone of Sardinia corresponds to the Massif Central Lower Gneiss Unit. Most of Variscan Corsica is occupied by a huge granitic batholith $[38,39,44]$ that encloses $\mathrm{km}$ - to $10 \mathrm{~km}$-sized septa of metamorphic rocks and migmatites [39,45]. The Zicavo and Porto Vecchio septa expose two tectonically superposed units, namely: (i) a micaschist and orthogneiss unit that is overthrust to the SW (in the present orientation, Figure 4) by (ii) an amphibolite-gneiss one. The two units are correlated with the Lower and Upper Gneiss units of the Massif Central, respectively. Migmatites and late-orogenic plutons widespread in Northern Sardinia and southern and central Corsica enclose blocks of eclogites and HP granulites (e.g., [38,39,44,46,47]); thus, the original extension of the Upper Gneiss Unit is presently unknown. It might be larger than the area depicted in Figure 4.

In NW Corsica (Argentella area), an undeformed Ordovician conglomerate and sandstone formation overlie the micaschists and amphibolites related to a Neoproterozoic basement (e.g., [39,45,48]). Such a pattern is similar to that found in the Central-North Armorican Domain where it is ascribed to the Cadomian orogen [19]. In NE Corsica, the Belgodère area is a migmatitic dome that encloses numerous blocks of ortho- and paragneiss, amphibolite, and eclogite. Radiometric constraints are still lacking there. The mafic magmatism is probably of Early Ordovician age. The metamorphic age is presently unknown, but it should be older than the Carboniferous age (ca $345 \mathrm{Ma}$ ) of the migmatite [45]. In this area, top-to-the- $\mathrm{N}$ or NE kinematic indicators are refolded by the doming [45]. More to the East, in the Agriates area, the Alpine overprint has totally erased the Variscan structures; nevertheless, some silicified sandstone and pelites, called "brown rocks", are ascribed to the Neoproterozoic [39]. On the basis of lithology and sense of shearing, the Belgodère-Agriates areas have been correlated to the Saxo-Thuringian Domain [45].

The Maures-Tanneron massif is easily compared to the metamorphic units of northern and central Sardinia (e.g., [49-51]). Thus, along with the Sardinia to Corsica transect, a bivergent architecture of this Variscan segment can be reconstructed with three domains: (i) a top-to-the-South nappe stack derived from the N. Gondwana margin, (ii) a Neoproterozoic intermediate block with undeformed Paleozoic series, correlated to Armorica, (iii) and Northeast-directed units belonging to the Saxo-Thuringian Domain (Figure 4).

\subsection{The Variscan Belt in the West Alpine Helvetic Basement}

Following an enormous amount of work, the Cenozoic Alpine orogen is subdivided into four lithotectonic domains: (i) the external or Helvetic; (ii) the internal or Penninic; (iii) the Austroalpine, and (iv) the South Alpine domains. The former two domains belong to the European continent whereas the latter two belong to Apulia (Figure 5). The Austroalpine Domain overlies the Liguro-Piemonte zone that corresponds to the remnants of the intervening Mesozoic ocean; and the Insubric line is the northern boundary of the South Alpine Domain. This four-fold Alpine subdivision is inappropriate to decipher the Variscan zonation since it is independent of the Variscan litho-tectonic domains presented in Section 2, even if locally some Paleozoic crustal discontinuities, such as the Penninic front, might have been reused during the Alpine cycle (e.g., [40]). Nevertheless, in order of 
clarity, the Alpine subdivision will be used here as it is geographically convenient. From the tectonic point of view, the term basement will be reserved for the rocks that experienced the Devonian to early Carboniferous Variscan orogeny. In this sense, the Late Carboniferous or Permian granitoids are not relevant to the Alpine basement since they were emplaced after the main Variscan tectonic or metamorphic phases (e.g., [4,52] and enclosed references).

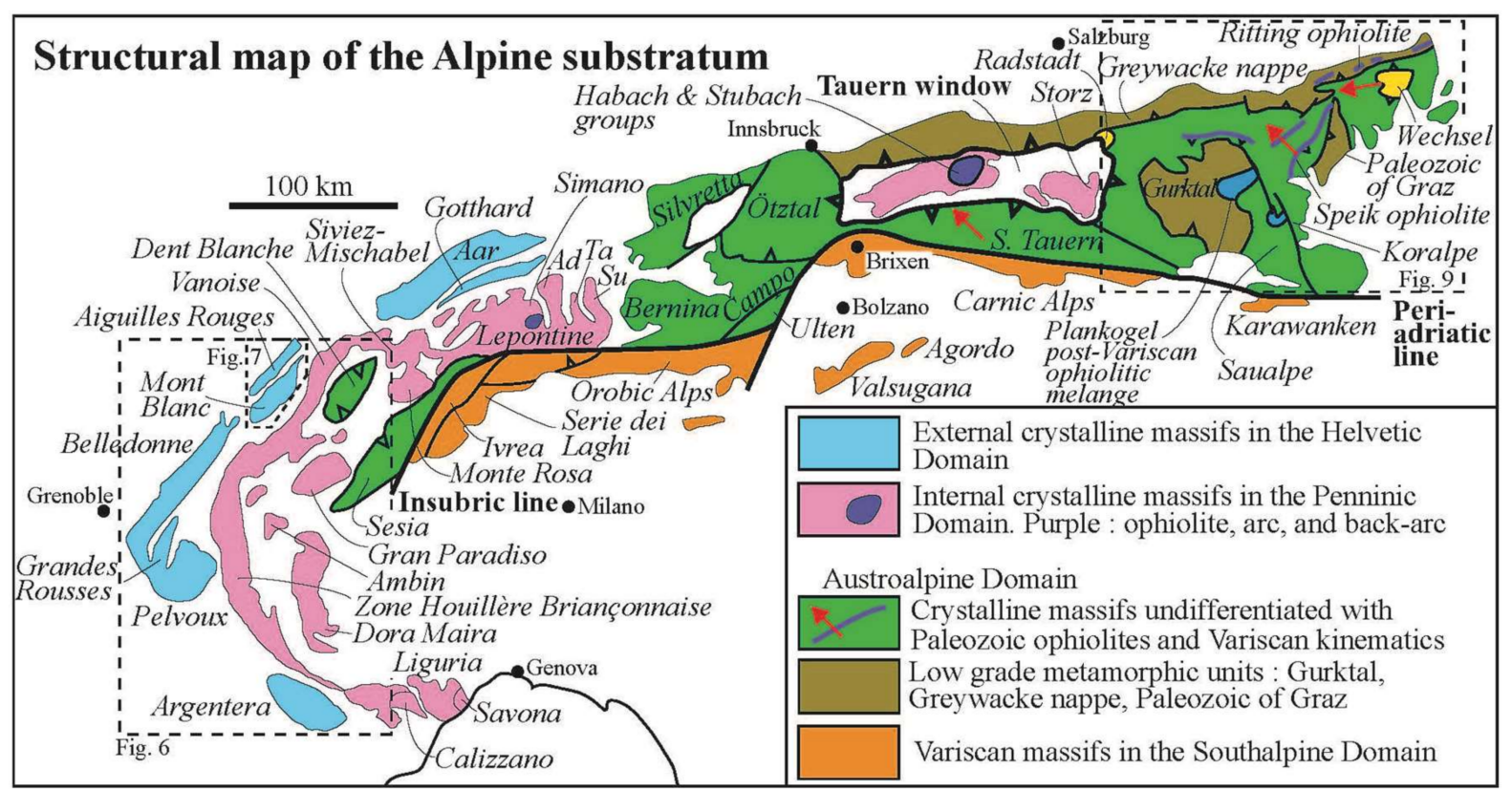

Figure 5. Tectonic map of the Alpine substratum showing the Paleozoic rocks involved in the Helvetic, Penninic, Austroalpine, and South Alpine domains. Ad: Adula, Ta: Tambo, Su: Suretta. Note that the term "substratum" includes both the pre-Middle Carboniferous basement already deformed during the Variscan orogeny, and the Late Carboniferous or Permian sedimentary formations and magmatic rocks that experienced only the Alpine orogeny.

In the Helvetic zone, the Variscan basement is exposed in the External Crystalline massifs of Argentera, Pelvoux, Grandes Rousses, Belledonne, $\mathrm{M}^{\mathrm{t}}$-Blanc, Aiguilles Rouges, and Aar-Gothard (Figures 5 and 6). Due to the weakness of the Alpine overprint, the pre-Permian geology of the External Crystalline massifs has been investigated since a long time (e.g., $[4,9,13,36,38,53-59])$. However, the widespread crustal melting erased the early structures. For instance, HP/HT metamorphic rocks are exposed as blocks in the migmatites of the Pelvoux, Argentera or Aiguilles Rouges massifs, but the associated structures are not deciphered (Figure 6). With respect to the early Variscan structures, the southern part of the Belledonne massif appears as one of the key areas. Since it has been recently investigated, only a brief outline is provided below (for details, see [57,59]).

The Belledonne massif is subdivided into western and eastern branches by the subvertical dextral "Synclinal Médian fault" that corresponds to a polydeformed structure since unmetamorphosed Triassic sedimentary rocks are involved in the brittle faulting. The western Belledonne branch consists of alternations of almost unmetamorphozed sandstone and mudstone of Ordovician age weakly deformed by tight upright folds. On the contrary, the eastern Belledonne branch yields three litho-tectonic units, namely: (i) the Chamrousse ophiolites, (ii) the Rioupeyroux-Livet unit, and (iii) the Taillefer series (Figure 6). The Chamrousse ophiolites of ca 500 Ma magmatic age $[60,61]$ consist of several thrust sheets, globally inverted as the serpentinized ultramafics and basaltic pillow lava from the upper and lower parts of the nappe stack, respectively. As a whole, the Chamrousse ophiolite was obducted at 380-360 Ma, whereas the synmetamorphic top-to-the-East shearing, coeval with East-directed thrusting, developed between 350 and $340 \mathrm{Ma}$ [57]. The underlying Rioupeyroux-Livet unit is a volcanic-sedimentary formation with subordi- 
nate Devonian magmatic rocks. This unit experienced a MP/MT metamorphism with biotite-garnet-staurolite \pm kyanite assemblage coeval with a top-to-the-E (or NE) ductile shearing [57]. Lastly, the Taillefer terrigenous and volcanic series unconformably overlies the Rioupeyroux-Livet unit, but the precise unconformity is difficult to recognize. The initial sedimentary contact was probably reworked as a decollement layer. Furthermore, the Taillefer series is also deformed by a subvertical NNE-SSW striking cleavage and a steeply dipping stretching lineation that denotes an east-west shortening after the nappe emplacement.

In the Grandes Rousses, Pelvoux, and northeastern part of Belledonne massif, Ordovician granites now transformed into orthogneiss, and leptynite-amphibolite complexes are well exposed but their tectonic relationships with the three units described above are unknown due to late faulting, and their involvement in migmatites. Among the other External Crystalline massifs, the SW part of the Aiguilles Rouges (Figure 7A) exposes lithologies similar to those of eastern Belledonne. Migmatites including blocks of Ordovician orthogneiss, micaschist, and eclogite are recognized (e.g., [10,13,62,63]). Deformed Visean volcanic-sedimentary rocks are also acknowledged in the Aiguilles Rouges and $\mathrm{M}^{\mathrm{t}}$-Blanc massifs. However, the relationships between these series and the underlying migmatite are not documented. According to Dobmeier [62], the Early Carboniferous greenschist facies metasediments and the migmatites are deformed by NE-vergent folds (Figure 7B). Moreover, these deformation structures are intruded by Visean granitoids dated at ca $330 \mathrm{Ma}$ [63-65].

Due to the abundance of metamorphic and plutonic rocks, the External Crystalline massifs are often correlated to the Moldanubian Domain that would have been translated to the Southwest from the Bohemian Massif by the East Variscan Shear Zone (EVSZ, [7,9-11,13]). The EVSZ is well documented in the Maures-Tanneron and NW Sardinia (e.g., [8,12,51,66-69]), ductile strike-slip faults are also recognized in the Argentera, and Aiguilles Rouges massifs [11,13], but they remain poorly localized in the External Crystalline massifs (see for instance [9] and [40]). Its time of activity varies from 330-340 Ma in the Argentera and $320 \mathrm{Ma}$ in the Aiguilles Rouges and Maures-Sardinia areas [13]. Moreover, even if small-scale ductile dextral shear zones can be locally recognized, the total amount of displacement is yet not settled. As leptynite-amphibolite complexes, Ordovician granitoids (now orthogneiss), and migmatites are widespread both in the Moldanubian and the SaxoThuringian domains, the lithology and metamorphic grade are not sufficient criteria to recognize to which Variscan domain the External Crystalline massifs belong.

The significance of the Chamrousse ophiolites appears as one of the key elements to discriminate the Variscan domains. Although there is a general agreement to interpret the Chamrousse ophiolite as formed during the Late Cambrian-Early Ordovician rifting, its geodynamic significance remains controversial. For some authors (e.g., [10]), the Chamrousse oceanic basin opened between the Armorica and Moldanubian domains, and closed by a NW-directed thrusting. Another interpretation argues that the Chamrousse oceanic basin developed between the Moldanubian and the Intra-Alpine (or Galatian) terrane [4]. The basin closure was accommodated by east-directed thrusting [2]. Our field observation complies with a top-to-the-East thrusting [57]. Considering: (i) the weak synmetamorphic deformation experienced by the western branch of the Belledonne massif, (ii) the overall east-directed ductile shearing of the ophiolites, and (iii) the MP/MT metamorphism coeval with a top-to-the-East shearing of the Rioupeyroux-Livet unit that underlies the ophiolitic nappe, it is difficult to place the root zone of the ophiolites West of the western branch of the Belledonne massif. Such a western location would imply that the rocks of the western branch of the Belledonne massif have experienced a synmetamorphic ductile deformation higher than what is presently observed. Therefore, another possibility is to locate the Chamrousse ophiolitic suture to the east of the western branch. The Synclinal Médian fault appears as the most likely possibility since a suture zone located farther East of Belledonne would not be in agreement with the kinematics recorded in the ophiolitic nappe and the Rioupeyroux-Livet unit. 


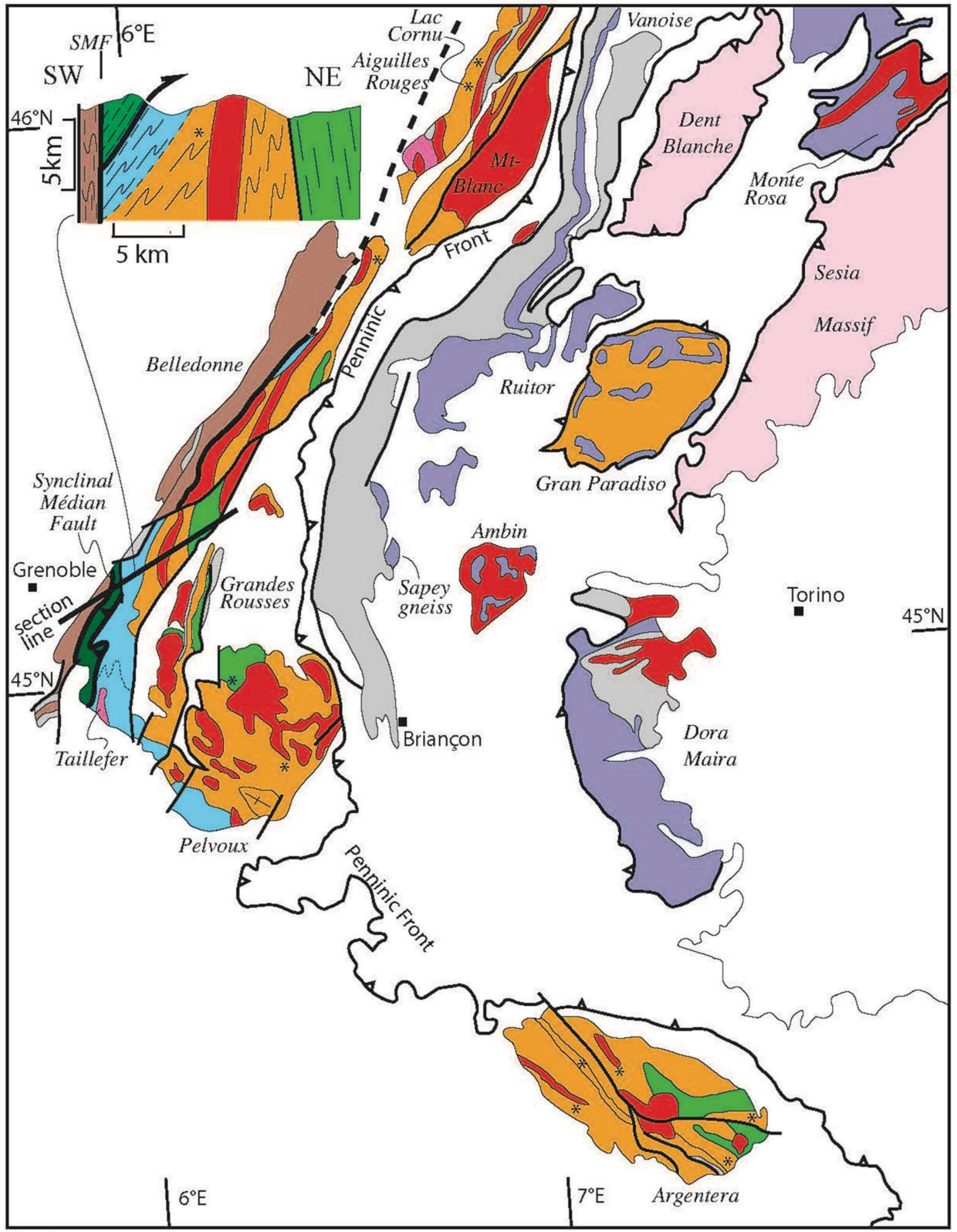

W. Belledonne sandstone and micaschists Chamrousse ophiolite (ca $500 \mathrm{Ma}$ ) Bimodal magmatic rocks and biotite-garnetstaurolite micaschists Rioupéroux-Livet and Le Chaillol Units

Leptynite-amphibolite complex

Conglomerate, schist, acidic volcanites

(ca $330 \mathrm{Ma}$ ) Taillefer series

Migmatites with various blocks

(*: eclogite or HP granulite)

Late Carboniferous clastic series (Briançonnais) Late Carboniferous granitoids

Variscan metamorphic rocks with strong Alpine overprint

Variscan metamorphic rocks in the Austroalpine units (Dent Blanche, Sesia)

$\checkmark$ Variscan tectonic contacts

A Alpine tectonic contacts

Chamrousse ophiolitic suture

Figure 6. Structural map of the Variscan basement in the Western Alps: Helvetic Crystalline massifs (Argentera, Belledonne, Grands Rousse, Pelvoux, Mt-Blanc, Aiguilles Rouges, Aar Gothard); Briançonnais substratum; Penninic crystalline massifs (Dora Maira, Ambin, Gran Paradiso, Monte Rosa). The cross section of the S. Belledonne massif is located in the map. From West to East, the Penninic front separates the External (or Helvetic) and Internal (or Penninic) domains. 


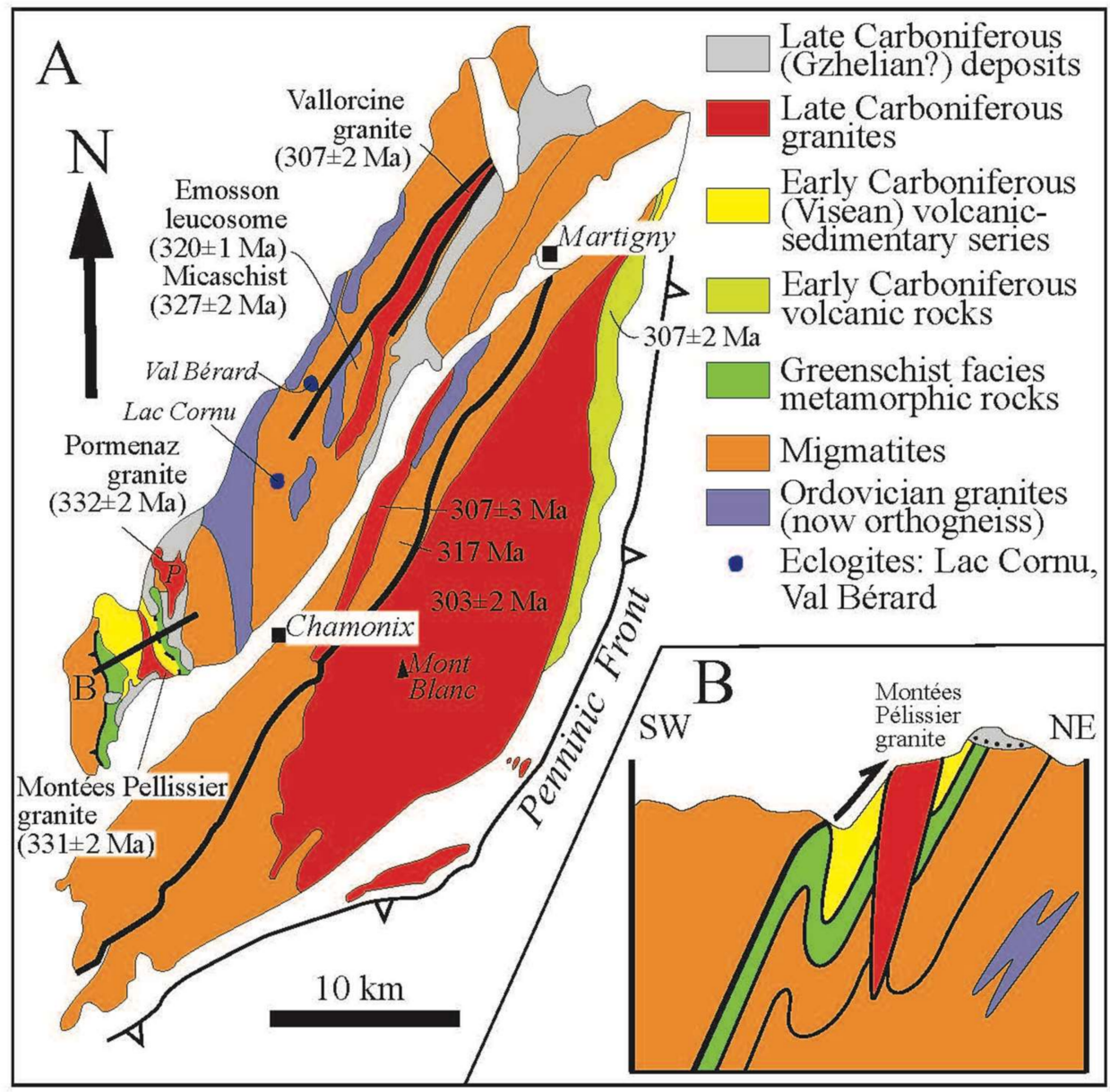

Figure 7. (A): structural map of the Mont-Blanc-Aiguilles Rouge massifs, and (B): cross-section of the Southwestern part of the Aiguilles Rouges massif (redrawn from [61]). This massif does not show any ophiolitic suture, but only eclogite derived from Ordovician mafic protoliths (gabbro, dyke, and lava flow) intrusive into a pelitic-sandstone formation. Ordovician granites are also intrusive in this series. Fold vergence and thrusts document NE-directed kinematics older than the $332 \pm 2 \mathrm{Ma}$ (Late Visean) plutons $[13,52]$.

Following this interpretation, the weakly deformed and metamorphozed rocks of the Belledonne western branch cannot be correlated to the Moldanubian Domain that exhibits high-grade metamorphic rocks. On the contrary, the unmetamorphozed formations of the Belledonne western branch can be considered as a part of the Armorican Domain, as already suggested [10]. Thus, in this view, the entire metamorphic rocks of the Belledonne eastern branch should be correlated to the Saxo-Thuringian Domain. At the larger scale of the External Crystalline massifs, the northern and southern cartographic extensions of the Belledonne eastern branch: the $\mathrm{M}^{\mathrm{t}}$-Blanc, Aiguilles Rouges, Pelvoux, and Argentera massifs that are lithologically similar to the eastern branch of the Belledonne massif must also belong to the Saxo-Thuringian Domain (Figure 6). Consequently, the Chamrousse ophiolites should be ascribed to the Tepla-Le Conquet suture.

\subsection{The Variscan Basement of the Penninic Zone}

From South to North, the Penninic crystalline substratum is exposed in the Internal Crystalline Massifs of the western Alps, namely: Liguria, E. Briançonnais, Dora Maira, Ambin, Gran Paradiso, Vanoise, Mte-Rosa, Lepontine Alps, and to the NE Tauern window (Figures 5 and 6). This internal zone of the West Alpine orogen experienced an intense synmetamorphic ductile shearing during the Cenozoic events at ca 50-35 Ma (e.g., [40,70] 
and enclosed references). Most of the protoliths of the Alpine gneiss are Late Carboniferous or Permian granites, and Late Carboniferous sandstones, conglomerates, and pelites similar to some extent to a late-orogenic molassic formation (e.g., $[40,71])$. Since these rocks never experienced the Variscan orogeny, they must be considered only as a pre-Alpine substratum but not a real basement.

In the true Variscan basement, a pre-Late Carboniferous barrowian metamorphism is substantiated at the mineral scale in some micaschists and gneiss, for instance in the Ambin, Ruitor, Gran Paradiso, E. Briançonnais (e.g., [40,71-75]). Muscovite and biotite yield ${ }^{40} \mathrm{Ar} /{ }^{39} \mathrm{Ar}$ ages ranging between 360 and $340 \mathrm{Ma}$ [76]. Ordovician granites (ca 470-440 Ma), and felsic volcanites are also widespread (e.g., [77]), but the Variscan pervasive structures are rarely preserved.

In the Ligurian Alps (Figure 5), the orthogneiss, paragneiss, metarhyolites, and amphibolites of the Calizzano and Savona massifs, a ductile deformation is documented by sigmoidal gabbroic boudins or sigma-type porphyroclastic augen gneiss [78,79]. It is worth noting that in this area, no ophiolitic remnants have been described yet. Although preliminary, a top-to-the-East (NE) shearing can be observed there.

Meter- to plurimeter-sized mafic and ultramafic boudins are scattered in the Penninic basement. Most of them are considered as Permian dykes intruding the gneissic continental crust. However, some Cambrian to Ordovician mafic-ultramafic associations are interpreted as ophiolites or ophiolitic mélange (e.g., [80,81]). In the Lepontine Alps (Figure 5), the amphibolites of the Simano nappe yields geochemical signatures suggesting a magmatic arc setting. Zircons from these rocks yield SHRIMP U/Pb ages at $518 \pm 11 \mathrm{Ma}$ (Early Cambrian) for the mafic protoliths [81].

Lastly, the core of the Tauern window exposes micaschists, paragneiss, and orthogneiss ascribed to the European plate overlain by the Alpine ophiolite bearing Penninic nappes ([82]; Figure 5). Several generations of granitoids (now changed into Alpine orthogneiss) have been recognized (e.g., [83-86] and enclosed references). In addition to the Late Carboniferous and Permian granitic intrusions, the basement rocks of the Tauern window expose two main lithological units [83-85]. The Habach Group consists of amphibolite derived from a basaltic protolith, paragneiss, micaschist, meta-graywackes and meta-conglomerates derived from terrigenous and volcanic formations. The Stubach Group is formed by amphibolite, paragneiss, and ultramafic bodies. The former group is interpreted as part of an arc or fore-arc complex related to the oceanic subduction of the Rheic ocean, whereas the latter one is considered as formed in an oceanic basin [84]. The oldest orthogneiss, derived from calc-alkaline granites and granitoids emplaced in the Habach arc, yield zircon U/Pb SHRIMP ages at ca $375 \pm 10 \mathrm{Ma}$ Ma [83]. The volcanic-sedimentary formations of the Stubach Group are ascribed to the Saxo-Thuringian Domain [83,84].

In conclusion, although most of the Variscan structures have been erased by the Alpine events, a few remains of East-directed shearing are locally preserved in the Penninic Domain of the western Alps. Furthermore, the presence of a Paleozoic active continental margin represented by ophiolitic remnants, magmatic arc series, and back-arc basin sediments are exposed in the Lepontine Alps and Tauern window, at the eastern part of this domain.

\section{The Variscan Massifs in the South Alpine Domain}

The Insubric, Tonale, Judicaria, and Peri-Adriatic faults, grouped as the Peri-Adriatic Line, represent the northern boundary of the South Alpine Domain that belongs to Apulia. The southern part of this domain is covered by Mesozoic and Cenozoic sediments (Figures 6 and 8). The South Alpine domain exposes several pre-Permian basement massifs deformed and metamorphozed during the Variscan orogeny. Geographically, from West to East, they are: the Ivrea zone, Serie dei Laghi, Orobic Alps, Brixen-Valsugana, Carnic Alps, and Karawanken massif. Since Apulia corresponds to the upper plate of the Alpine collision, the South Alpine Domain experienced a localized Alpine deformation, mostly characterized by S-directed thrusts and shear zones between which the Variscan pervasive synmetamorphic structures are well preserved (e.g., [87-89]). The macroscopic regional 
foliation, cross-cut by Late Carboniferous or Permian plutons and covered by Permian volcanites, developed during the Variscan orogeny [90]. Numerous petrological and structural works have been dedicated to the Variscan features of the South Alpine Domain (e.g., [1,72,73,91-101]). In the following, only the main metamorphic and structural features are presented; for details, readers are invited to refer to the above-cited articles.

\subsection{The Ivrea Zone}

This area is famous as one of the rare places in the world where the lower continental crust made of mafic and felsic granulites and kinzigites is widely exposed at the surface. Such lithologies are considered as forming the layered lower continental crust observed in the seismic profiles or scavenged by Cenozoic volcanoes. The Ivrea HT metamorphic rocks developed in the Late Carboniferous, Permian, i.e., during the Late- to post-Variscan stages of the orogeny. Therefore, the Ivrea zone will not be considered below as it does not bear information on the architecture of the Variscan orogen.

\subsection{The Serie dei Laghi (Lakes Series)}

To the SE of the Ivrea zone, the metamorphic rocks of the Lakes series are subdivided into three litho-tectonic units, from the NW to the SE: (i) the Strona-Ceneri, (ii) the Scisti dei Laghi, and (iii) the Val Colla schists, with decreasing metamorphic conditions (e.g., [102]). The Strona Ceneri unit consists of paragneiss, micaschists, metasandstone, conglomerates, and garnet amphibolites. Most of these amphibolites are retrogressed eclogites derived from basalts, volcaniclastic rocks, gabbro, and rare ultramafics [103]. The thermo-barometric conditions of the HP metamorphism are constrained at $710 \pm 30^{\circ} \mathrm{C}$, and ca $2.1 \mathrm{GPa}$, and dated at $457 \pm 5 \mathrm{Ma}$, and $443 \pm 19 \mathrm{Ma}$ by zircon and rutile $\mathrm{U} / \mathrm{Pb}$ method, respectively, implying ongoing subduction at that time [104]. The Strona Ceneri unit overthrusts the Scisti dei Laghi unit formed by biotite-garnet-staurolite-kyanite micaschists and metapelites. The sedimentary protoliths were intruded by Ordovician granites. In turn, the Scisti dei Laghi unit overthrusts the greenschist facies micaschists, quartz schists, phyllites, and epidote amphibolites of the Val Colla series.

\subsection{The Orobic Alps}

East of the Como lake, two main tectono-metamorphic units are recognized [92,96,102,105]. The northern one, sometimes called the Morbegno gneiss, consists of paragneiss with biotite-garnet-staurolite-kyanite assemblages characteristic of a barrowian MP/MT metamorphism $[92,97,99]$. These medium-grade metamorphic rocks, similar to the Scisti dei Laghi unit, overthrust an eastern or southeastern low grade (muscovite-chlorite) unit referred to as the Edolo schists [91-93,95-97,99-101].

\subsection{The Variscan Massifs of Brixen, Valsugana, and Agordo}

East of the Judicaria Line, the Variscan crystalline massifs consist of low-grade phyllites and quartz phyllites. From a structural point of view, these greenschist facies rocks have a gently dipping or flat lying foliation, and a N-S to NW-SE trending stretching lineation [106]. Kinematic indicators document both top-to-the SE, and top-to-the NW shear senses interpreted as burial- and exhumation-related structures, respectively. The quartz phyllite, with thermo-barometric conditions of $375 \pm 26{ }^{\circ} \mathrm{C}$ and $0.4 \mathrm{GPa}$, yield white mica ${ }^{40} \mathrm{Ar} /{ }^{39} \mathrm{Ar}$ ages at ca $319.0 \pm 5.5 \mathrm{Ma}[107]$.

\subsection{The Carnic Alps and Karawanken Unit}

The easternmost parts of the South Alpine Domain (Figure 5) are well known for their fossiliferous Paleozoic sedimentary series (e.g., $[107,108])$. Strongly deformed along the Peri-Adriatic Line, the Karawanken unit will not be considered in the following. In the Carnic Alps, the Late Paleozoic series are characterized by a Devonian limestone platform with Frasnian-Famennian red or white nodular limestone, called the Pal Grande formation deposited at a low latitude. After a short Famennian-Tournaisian chert (lydites and 
siliceous schists) deposition episode, the Carboniferous rocks consist of ca 1000-1500 m Visean to Bashkirian turbidite, pebbly mudstone, and olistostrome called the Hochwipfel formation. The Devonian-Carboniferous sedimentation represents an evolution from a drowning limestone platform progressively replaced by a syn-orogenic gravity-driven chaotic deposit [109]. The Paleozoic series of the Carnic Alps is deformed by South-verging overturned and recumbent folds of Serpukhovian to Bashkirian age. The Hochwipfel formation is a syntectonic series deposited in a foreland basin coeval with the development of folds and thrusts (e.g., [108,110-112]). At the km-scale, several nappes are recognized [112]. The Western and upper Fleons nappe experienced a syn-metamorphic ductile shearing with a southward displacement developed under epizonal metamorphic conditions (ca 300-400 ${ }^{\circ} \mathrm{C}$ ). According to Läufer et al. [112], the underlying units, called Cellon-Kellerwand, and Hochwipfel nappes, are deformed by south-verging folds and thrust, almost devoid of metamorphism.

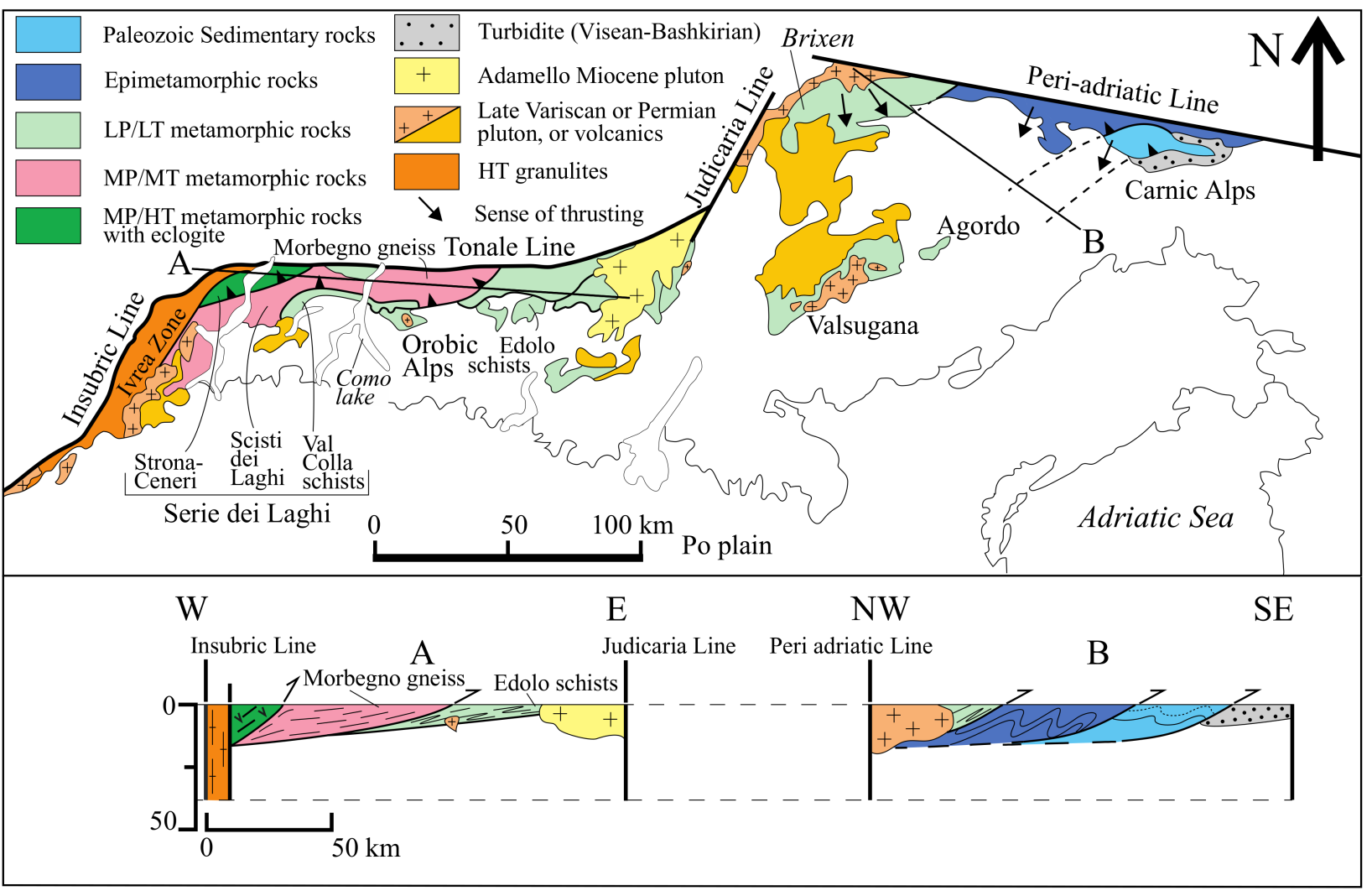

Figure 8. Structural map of the South Alpine Domain (redrawn after [96,102,106,112]). Synthetic cross-section from the Ivrea zone to the Carnic Alps along the lines A and B shown in the map.

The Carnic Alps presents striking lithological, structural, metamorphic and tectonic analogies with the southern part of the French Massif Central (Montagne Noire), Eastern Pyrenees, and southern Sardinia (Figures 2 and 4) in which a progressively subsiding Devonian carbonate platform of Gondwanian affinity was replaced by a foreland clastic basin in Visean to Bashkirian [113]. This sedimentological change was coeval with the development of a South-directed fold-and-thrust belt (e.g., [28,30,31,37,43,114]).

Considering the entire South Alpine Domain, as already pointed out by Vai and Cocozza [1] for the metamorphic zonation, a point-by-point comparison can be established with the southern part of the French Massif Central and the Sardinia-Corsica segment. The Strona Ceneri Unit with the HP/MT relics, the MP/MT metamorphic rocks of the Scisti dei Laghi-Morbegno gneiss, the low-grade Val Colla-Edolo-Brixen quartz phyllite schists, and the Carnic anchizonal to unmetamorphozed series can be correlated with the Upper 
Gneiss Unit, Lower Gneiss Unit, Para-autochthonous Unit, and Southern Fold-and-Thrust belt, respectively. Therefore, in spite of important displacements and rigid-block rotations developed since the Permian, the South Alpine Domain is interpreted here as the eastern extension of the Moldanubian Domain.

\section{The Variscan Fragments in the Austroalpine Nappe Stack}

With respect to the Variscan orogeny, the Austroalpine Domain is the most difficult realm to decipher, as the Variscan elements are scattered into numerous Alpine nappes thrust over the Penninic Domain (Figures 1 and 5). These units experienced widespread multiphase Permian (or pre-Alpine), and Cretaceous (or eo-Alpine), with some Cenozoic (or Alpine) tectono-metamorphic events and several hundred of kilometers of northward and westward displacement [115-117]. The Austroalpine stack is classically subdivided into Lower, Middle, and Upper nappes (e.g., [81,116,118-120]). Alike for the Helvetic and Penninic domains, this subdivision is not pertinent for the Variscan architecture since the Paleozoic lithological, structural, and metamorphic features are unrelated to the MesoCenozoic tectonics. Furthermore, the Variscan metamorphism and associated structures are rarely preserved in the Austroalpine nappe stack. In the following, we shall pay attention to the Variscan structures preserved in the Austroalpine stack developed East of the Tauern window (Figure 5). Firstly, the Paleozoic ophiolitic suites that represent first-order plate boundaries will be considered, and secondly an overview of the most representative tectonic units such as the low-grade Paleozoic series, and the high-grade metamorphic complexes will be introduced (Figure 5).

\subsection{The Ophiolitic Suites}

As oceanic lithosphere relics, ophiolites are key elements to separate the litho-tectonic domains corresponding to continents or microcontinents. In the Austroalpine Domain East of the Tauern window, three ophiolitic suites have been recognized [118,119,121]. Although dismembered and metamorphosed within the Alpine nappe stack, from north to south, they are the Ritting, Speik and Plankogel complexes (Figures 4 and 9).

The Ritting complex as part of the Kaintaleck slices is located below the low-grade Greywacke nappe (Figures 5 and 9). It consists of serpentinite, amphibolite, micaschist, quartzite, and marble boudins of Neoproterozoic to Early Paleozoic protolith age [122]. Amphibole from a retrogressed eclogite yields a Paleozoic ${ }^{40} \mathrm{Ar} /{ }^{39} \mathrm{Ar}$ age at $397 \pm 7 \mathrm{Ma}$ [123].

The Speik complex is formed by serpentinized peridotite, metabasalt, partly eclogitized metagabbro and oceanic sediments. The ultramafic rocks of the Speik ophiolitic complex yield a Sm-Nd age at $745 \pm 44 \mathrm{Ma}$, isochron age at $554 \pm 37 \mathrm{Ma}$, and Re-Os errorchrone age at $550 \pm 17 \mathrm{Ma}$ [124]. However, unpublished new zircon U-Pb ages from garnet amphibolite yield Early Ordovician ages ([125], F. Neubauer personal communication). This ophiolitic suite overthrusts biotite-plagioclase paragneiss and various kinds of ortho- and paragneiss called the "Core gneiss complex"(cf Section 5.3 below). The Speik ophiolitic complex is overlain by a Silurian-Devonian micaschist-marble complex. A stratigraphic contact with the underlying ophiolite is assumed (e.g., [118]) but in agreement with [125], a thrust contact is preferred here as ophiolitic suites, representative of oceanic lithosphere, are allochthonous units obducted upon continental crust. The micaschist-marble complex is a piece of a continental block that tectonically overlies the Speik ophiolites. The Speik ophiolites are presently interpreted as formed in a back-arc basin ([125], see Section 5.3.1 below). 


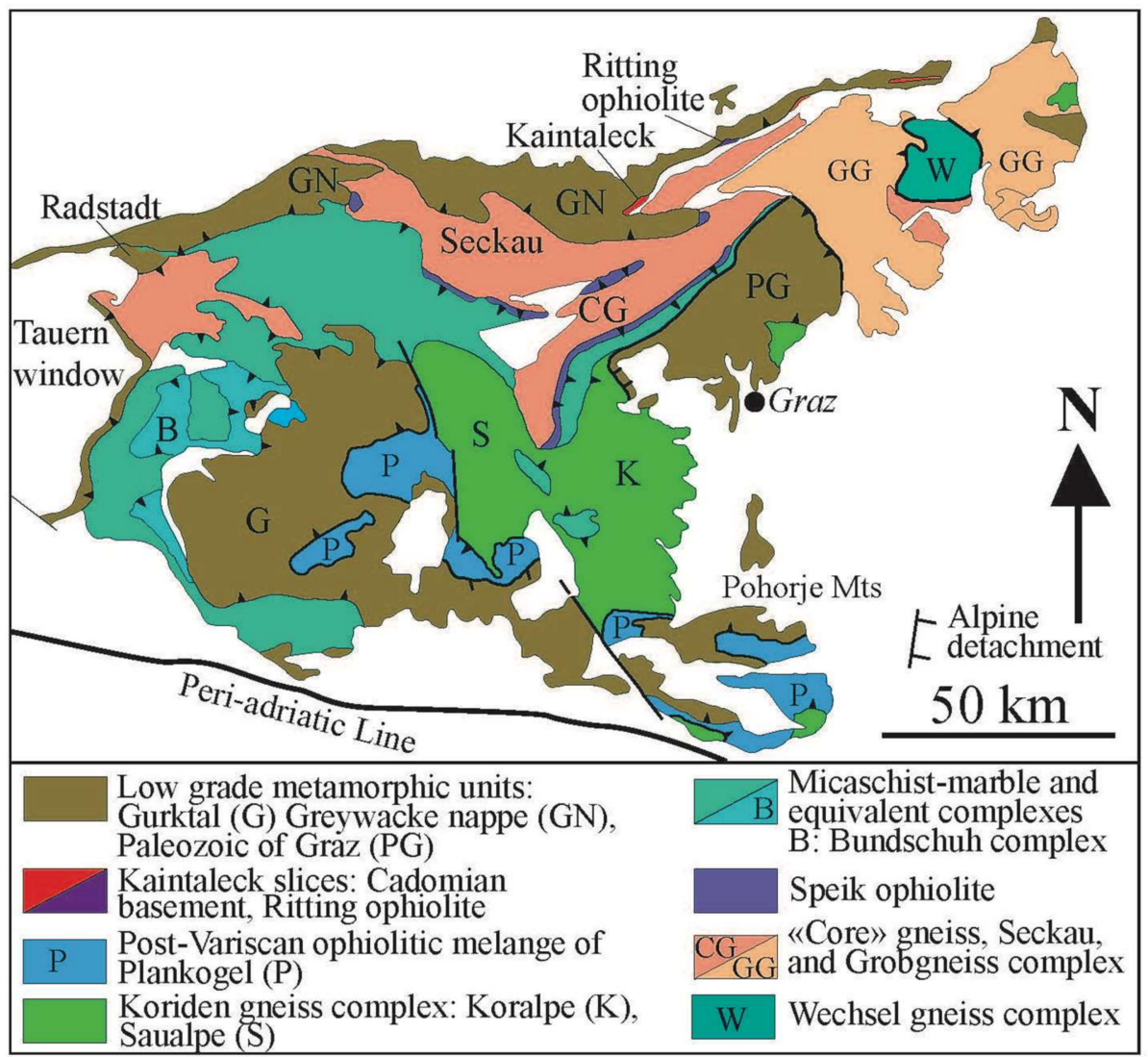

Figure 9. Tectonic map of the Austroalpine Domain east of the Tauern window. The Ritting, and Speik ophiolites subdivide the Variscan units into three main groups, namely: (i) the low-grade metamorphic units (Gurktal nappe, Greywacke nappe, and Paleozoic of Graz), (ii) the Koriden gneiss, and Micaschist-marble complexes, and (iii) the "Core" gneiss, Grobgneiss, and Wechsel gneiss complexes (simplified from [118]). For the interpretation of nappe architecture, see Figures 10 and 11.

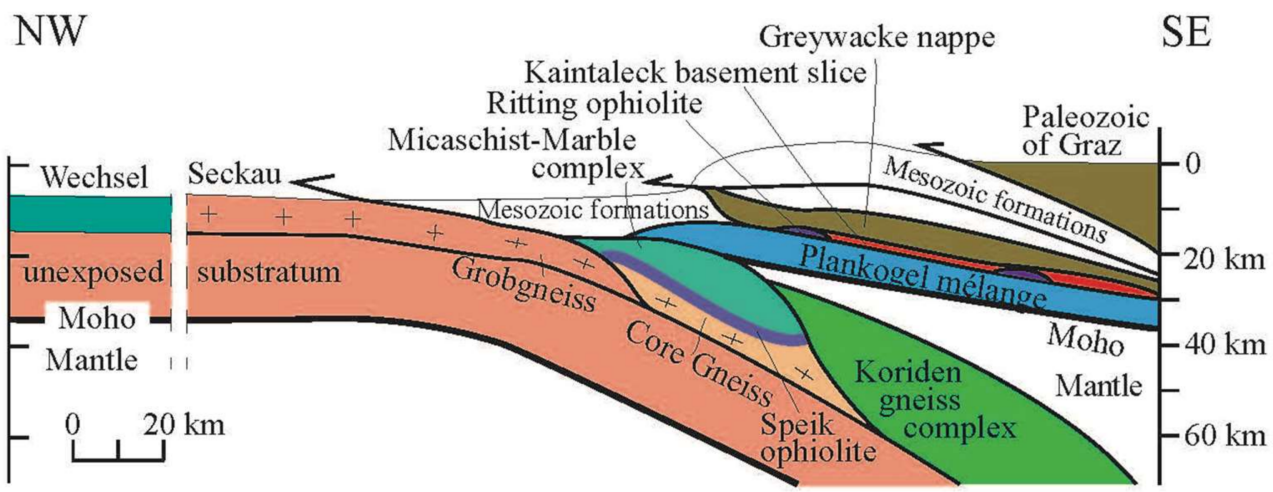

Figure 10. Crustal scale cross-section of the Austroalpine nappe stack during the Cretaceous (EoAlpine) event. The underlying plate consists of the Seckau, "Core" Gneiss and Grobgneiss complexes. The Wechsel Complex is assumed to belong to the same plate. The Speik ophiolite separates this piece of continental crust below, and an upper one formed by the Micaschist-marble and Koriden-gneiss complexes. The post-Variscan Plankogel ophiolitic mélange separates this lower edifice from an upper one formed by the Ritting ophiolites, the Neoproterozoic Kaintaleck basement and the low-grade metamorphic units (Greywacke nappe, and Paleozoic of Graz). The Mesozoic units are left in white (modified from [115]). 


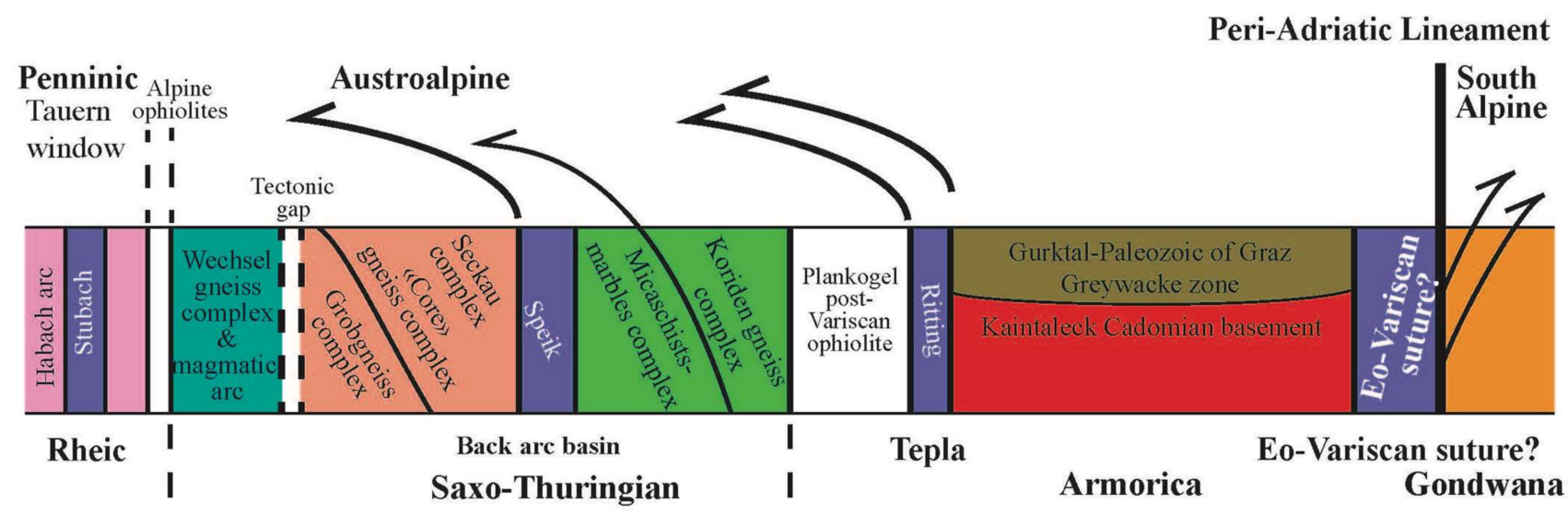

Figure 11. Tentative restoration of the Variscan belt by unravelling the litho-tectonic units involved in the Austroalpine nappe stack. The Speik ophiolite, interpreted as a back-arc basin, opened in a single continental terrane ascribed to the Saxo-Thuringian Domain. In spite of the Alpine tectonic gap, the Wechsel gneiss complex, interpreted as a magmatic arc, is also ascribed to the Saxo-Thuringian Domain. The Ritting ophiolitic suture separates Saxo-Thuringian and Armorican Domains. The South Alpine Variscan units are correlated to the Moldanubian Domain that belongs to the N. Gondwana margin. The Stubach ophiolite is ascribed to the Rheic suture.

The Plankogel complex is a serpentinite mélange with micaschist, basalt, marbles, and quartzite blocks enclosed in a silty-sandy matrix. The Plankogel mélange was originally considered as a Variscan ophiolitic mélange $[118,119]$. However, new data show that it was metamorphosed during Permian times [125], and was reworked by the Late Cretaceous eoAlpine tectonics that followed the closure of the Meliata ocean [126]. The top-to-the-South (or the ESE) synmetamorphic kinematic indicators are related to the Plankogel detachment that accommodated the exhumation of HP to UHP rocks (e.g., $[115,127,128])$. Thus, in the following, the Plankogel mélange will not be considered to unravel the Variscan orogeny. When dealing with the Variscan tectonics, only the Speik and Ritting ophiolitic suites of Neoproterozoic to Early Paleozoic age represent oceanic realms that separated continental crust elements.

\subsection{The Low-Grade Metamorphic Units}

In the Austroalpine nappe stack, phyllites and quartz-phyllites are exposed in several allochthonous units such as the Paleozoic of Graz, the Gurktal thrust system, and the Greywacke nappe (Figures 5 and 9); (see [129] for details). Lithologically, these units are dominated by phyllitic rocks and volcano-clastites with minor amounts of calcschist and limestone. Conodonts, acritachs and palynomorphs document a Late Silurian to Early Pennsylvanian age for these series. The sedimentary successions include abundant Ordovician acidic and felsic volcanics with alkaline lava flows and dykes. This bimodal magmatism complies with an Ordovician rifting event that took place within an intraplate basin [130].

In spite of a Late Cretaceous overprint, low angle thrusts and recumbent folds are documented in the Paleozoic of Graz [131]. The paleogeographic reconstruction suggests that the low-grade metamorphic rocks were deposited in a marine basin underlain by a continental basement open to the NW (in the present coordinates). The basin was subsequently inverted during the Early Pennsylvanian [129]. The low-grade rocks of the Greywacke nappe, exposed in the northern part of the Austroalpine stack tectonically overlie the Kaintaleck slices that contain a metamorphic basement and the Ritting ophiolites [122]. Muscovite and amphibole yield Early Paleozoic ${ }^{40} \mathrm{Ar} /{ }^{39} \mathrm{Ar}$ ages at $380-350 \mathrm{Ma}$, and 430-405 Ma, respectively [132]. To the South, the Gurktal nappe and the Paleozoic of Graz overthrust the Plankogel ophiolitic mélange ([118], Figure 9). 


\subsection{The Crystalline Complexes}

Various metamorphic complexes are recognized in the Austroalpine nappe stack (Figure 5). The Variscan age of some of the metamorphic rocks is supported by the intrusion of the undeformed to weakly foliated Late Carboniferous or Middle-Late Permian granitic plutons (e.g., [133,134]). On the basis of the position of the Speik ophiolitic suite, it is possible to distinguish a lower group of units formed by the Seckau, "Core" gneiss, Grobgneiss, and Wechsel complexes, and an upper group formed by the Micaschist-marble, and Koriden gneiss complexes (Figure 9).

\subsubsection{The Lower Metamorphic Complexes}

The "Core" gneiss complex and the Seckau nappe consist of micaschists, paragneiss, orthogneiss, and felsic gneiss-amphibolite alternations (e.g., [118,134]). In the Seckau nappe, the Late Cambrian-Early Ordovician plutons of the Hochreichart suite intrude a Neoproterozoic (ca 570-560 Ma) metamorphic series (the Glaneck suite) formed during the Cadomian orogeny, followed by Late Devonian to Early Carboniferous plutons [134]. The Grobgneiss complex presents many resemblances with the "Core" gneiss complex, but abundant Middle Permian migmatites are also widespread [135].

The Wechsel gneiss complex, exposed in an Alpine tectonic window, is the lowermost part of this group of Variscan units (Figure 9). According to Neubauer et al. [136], it is subdivided into several litho-tectonic units [136], and enclosed references). Namely, from bottom to top, the Wechsel Gneiss Complex, in turn subdivided in lower Monotonous, and upper Variegated Gneiss complexes, followed by the Wechsel Phyllite Unit that consists of chlorite-muscovite-albite paragneiss, micaschist, blackschist, and quartz-phyllite with subordinate actinolite-epidote amphibolite. The Wechsel Gneiss and Phyllite units are tectonically overlain by the Waldbach Basement made of amphibolites, micaschists, orthoand para-gneiss tectonically overlain by the Grobgneiss complex. The kinematic indicators coeval with the synmetamorphic deformation document a top-to-the-W or SW ductile shearing ascribed to the eo-Alpine tectonics [118,137]. However, white mica populations and whole rock yield $\mathrm{Rb} / \mathrm{Sr}$ and ${ }^{40} \mathrm{Ar} /{ }^{39} \mathrm{Ar}$ ages around $380-370$ Ma overprinted by Mesozoic ones [137]. The detrital zircon age distribution of rocks from the Variegated Gneiss Complex shows a peak between 2.5 and $2.1 \mathrm{Ga}$ that supports a Gondwanian affinity for the source of the detrital zircons.

\subsubsection{The Upper Metamorphic Complexes}

From bottom to top, the upper group of metamorphic rocks that overlies the Speik ophiolite consists of a Micaschist-marble complex considered as derived from Ordovician to Devonian pelite and carbonate protoliths, followed by a series of biotite-garnet-kyanite metapelites exposed in the Koralpe and Saualpe areas [118]. The Bundschuh para-and orthogneiss complex that yield Ordovician ages (F. Neubauer, personal communication, Figure 9) is also tentatively placed in the upper metamorphic group.

\subsubsection{The Western and Southern Variscan Metamorphic Complexes}

West and South of the Tauern window, several Variscan metamorphic complexes are exposed in the Silvretta, Ötzal, Bernina, Campo, Ulten, and South-Tauern nappes (e.g., [4,116]; Figure 5). The detail of the Variscan structure of these complexes is incompletely clarified yet.

In the Silvretta nappe, which is considered as the western equivalent of the Seckau nappe, mafic gneiss derived from gabbro, tonalite, and diorite plutons that yield zircon U-Pb Neoproterozoic-Early Cambrian ages, ranging from $610 \mathrm{Ma}$ to $525 \mathrm{Ma}$, [138] are interpreted as emplaced in a continental arc setting. Moreover, an oceanic plagiogranite dated at $532 \pm 30 \mathrm{Ma}$ is considered as a piece of an ophiolitic crust [139]. Thus, the metamorphic rocks of the Silvretta nappe document a Neoproterozoic-Early Paleozoic evolution characterized by the formation of a Cadomian basement, intruded by ca 475-467 Ma (Ordovician) plutons, and subsequently involved in the Variscan orogeny [138-143]. 
The litho-tectonic units distinguished in the metamorphic series exposed in the South Tauern area also experienced a Variscan top-to-the NW syn-metamorphic ductile shearing $[117,144,145]$.

\subsection{The Relative Arrangement of the Variscan Units in the Austroalpine Nappe Stack}

In spite of many uncertainties, a speculative and qualitative restoration of the Variscan elements scattered in the Austroalpine Domain is proposed in this section. The multiple Variscan units presented in the previous sections are included in an extremely complex stack of Alpine nappes, with both East to West, and South to North displacements developed during the eo-Alpine and Alpine tectonics (e.g., [82,116]). In the Late Cretaceous, since the Cenozoic Alpine movements did not exist yet, a reconstruction of the Austroalpine bulk architecture corresponding to the eo-Alpine orogeny at ca 100-90 Ma provides a picture simpler than the present structure (Figure 10); (see [115,121,146] for details).

In order to unravel the effect of the Alpine tectonics, it is generally assumed that the geometrically highest nappes occupied the southernmost paleogeographic position since they experienced the largest displacement. In this view, the low-grade metamorphic units of the Greywacke nappe and its Neoproterozoic Kaintaleck basement should be rooted North of the Peri-Adriatic Line. Due to their lithological similarities, and for simplicity, the Gurktal and Paleozoic of Graz nappes are placed in the same unit together with the Greywacke nappe as proposed by Neubauer and Sassi ([129]; Figure 11). These nappes were thrust over the Ritting ophiolite that represents one of the Paleozoic oceans. North of the post-Variscan (i.e., Permian-Triassic) Plankogel ophiolitic mélange, the Koriden gneiss and the Micaschistmarble complexes are interpreted as two elements derived from the same continental block located South of the Speik ophiolites. More to the North, tectonically below the Speik ophiolites, the Seckau, "Core" gneiss, and Grobgneiss complexes correspond to pieces of the same continental block, the crust of which experienced ductile deformation and metamorphism during Variscan continental subduction. The Wechsel Gneiss Complex might belong to the distal part of this northern continent; however, the Alpine tectonic contact does not allow us to document the primary relationships between the Wechsel Gneiss Complex and the other metamorphic complexes (Figure 11). Nevertheless, since this metamorphic complex yields Paleoproterozoic detrital zircons with Gondwanian signatures, its place close to the Grobgneiss complex appears likely. Furthermore, the development of a magmatic arc in the Wechsel Gneiss Complex accounts well for the formation of the Speik back-arc basin $[125,136]$.

In summary, in the Austroalpine nappe stack, this relative arrangement of the Variscan units allows us to propose the following restoration. Considering that the Speik back-arc basin opened within a single continental block, the Wechsel Gneiss, Gross Gneiss, "Core" Gneiss Complex, Seckau, Micaschist-marbles, and Koriden Gneiss complexes are ascribed to the Saxo-Thuringian microcontinent. On the contrary, South of the Ritting ophiolite, the Kaintaleck Cadomian basement and its weakly metamorphosed Paleozoic sedimentary cover exposed in the Paleozoic of Graz, Gurktal, and Greywacke nappe are ascribed to the Armorica microcontinent (Figure 11).

\section{A Possible Interpretation: The Alpidic Orocline}

A palinspastic reconstruction of the Variscan orogen involved in the Western and Eastern Alps must obviously unravel the Alpine deformation and displacement, namely: (i) a limited (ca 40-50 km) northwestward translation in the Helvetic crystalline massifs (e.g., [147]), (ii) a rigid anticlockwise rotation of the southern part of the Western Alps massifs of Argentera, Liguria, and the South Briançonnais part of the Penninic zone [148,149] with respect of the northern part of the Helvetic Domain [23,148,149], (iii) a bulk shortening of ca $200 \mathrm{~km}$ of the European margin, mostly accommodated in the Penninic Domain by $\mathrm{km}$-scale north-verging recumbent folds, and thrust [150], (iv) a precisely unsettled north-to northwestward translation of the Austroalpine nappe stack, and South Alpine Domain. In the reconstruction discussed below, a rough ca $500 \mathrm{~km}$ displacement is assumed 
(e.g., [82,149-151] and enclosed references). Furthermore, the dextral displacement accommodated by the East Variscan Shear Zone have translated the Alpine External Crystalline Massifs to the SW $[9,10,13]$, but the total amount of displacement is not well constrained yet.

Therefore, qualitatively, in the Austroalpine and South Alpine domains, the following succession, from South to North, in the present-day coordinates, can be proposed (Figure 12):

1. The South Alpine units of Strona Ceneri, Serie dei Laghi, Brixen schists, and Carnic Alps, present significant lithological, metamorphic, and structural features suggesting that this domain consists of several nappes comparable to the Moldanubian Domain. In this framework, the northern boundary of this domain, called eo-Variscan ophiolitic suture (Figure 2), is missing. We argue that it has been erased by the Peri-Adriatic Line that represents a major lithospheric discontinuity,

2. The low-grade metamorphic units of the Greywacke nappe, Paleozoic of Graz and Gurktal nappe are interpreted as the Paleozoic sedimentary cover of a Neoproterozoic basement belonging to another continental block. That pattern suggests similarities with the Armorica microcontinent. The Ritting, and Silvretta ophiolites might be located at the northern boundary of this block.

3. A northern continent is represented by the Micaschist-marble complex, Koriden gneiss complex, the units South of the Tauern window, the micaschists and gneiss of the Wechsel, "Core" gneiss, and Grobgneiss complexes. This block includes also the Speik ophiolites formed in a back-arc basin and thus do not represent a true plate boundary. Moreover, in agreement with previous works $[123,133]$, we suggest that the Wechsel magmatic arc was formed in response to a south-directed oceanic subduction, followed by continental collision. These northern ocean and continent have been called Prototethys and Hunia/Galatia block, respectively [125,152]. However, in our terminology, the terms of Rheic suture and Laurussia (or Avalonia: i.e., the southern part of Laurussia) will be preferred, since they better emphasizes the place of the Alpine Variscan units in a unitary framework.

4. To the North of the Wechsel arc, an unexposed continental basement, ascribed here to Laurussia, is postulated in this palinspastic reconstruction (Figure 12).

Though the Variscan kinematics are not clearly established in all nappes, a northward sense of shear is documented, at least locally, in the last three areas, whereas a top-to-theSouth displacement is established for the South Alpine Domain (e.g., [106,112,117,130]; Figures 5 and 8; see Section 4 above). As discussed in Section 3, top-to-the-E shearing is documented in the External Crystalline massifs, NE Corsica, and probably Liguria (e.g., $[45,57,79])$.

At the scale of the entire Variscan belt exposed in the Western Alps, South Alpine and Austroalpine domains, the Chamrousse, Silvretta, and Ritting ophiolites are ascribed to the Tepla suture, whereas the Lepontine, and Stubach-Habach ophiolites and arc systems are correlated to the Rheic suture. The Speik ophiolite is interpreted as a back-arc basin opened to the South of the Wechsel arc. Furthermore, although presently not exposed, a continental crust ascribed to the Laurussia (or Avalonia) should also exist to the north of the Wechsel Gneiss Complex (see also [125]). This qualitative reconstruction of the basement massifs that does not consider the real amount of Late Carboniferous, Permo-Triassic and Meso-Cenozoic displacements defines a curved pattern, convex to the West, called here the "Alpidic orocline" (Figure 12). This newly proposed structure involves Gondwana-derived microcontinents such as Armorica, and Saxo-Thuringian Domain that before the Cretaceous were located to the South of the Moesia platform corresponding to Laurussia. During the Late Mesozoic and Cenozoic, this orocline was reworked by the complex tectonic evolution of the Alpine-Carpathian orogen (e.g., [153,154]). Furthermore, the difficulty to recognize the Alpidic orocline might also be due to the reactivation of Late Variscan shear zones by the Late Permian dextral megashear between Laurussia and Gondwana that transformed Pangea B to Pangea A (e.g., [155-157]). 


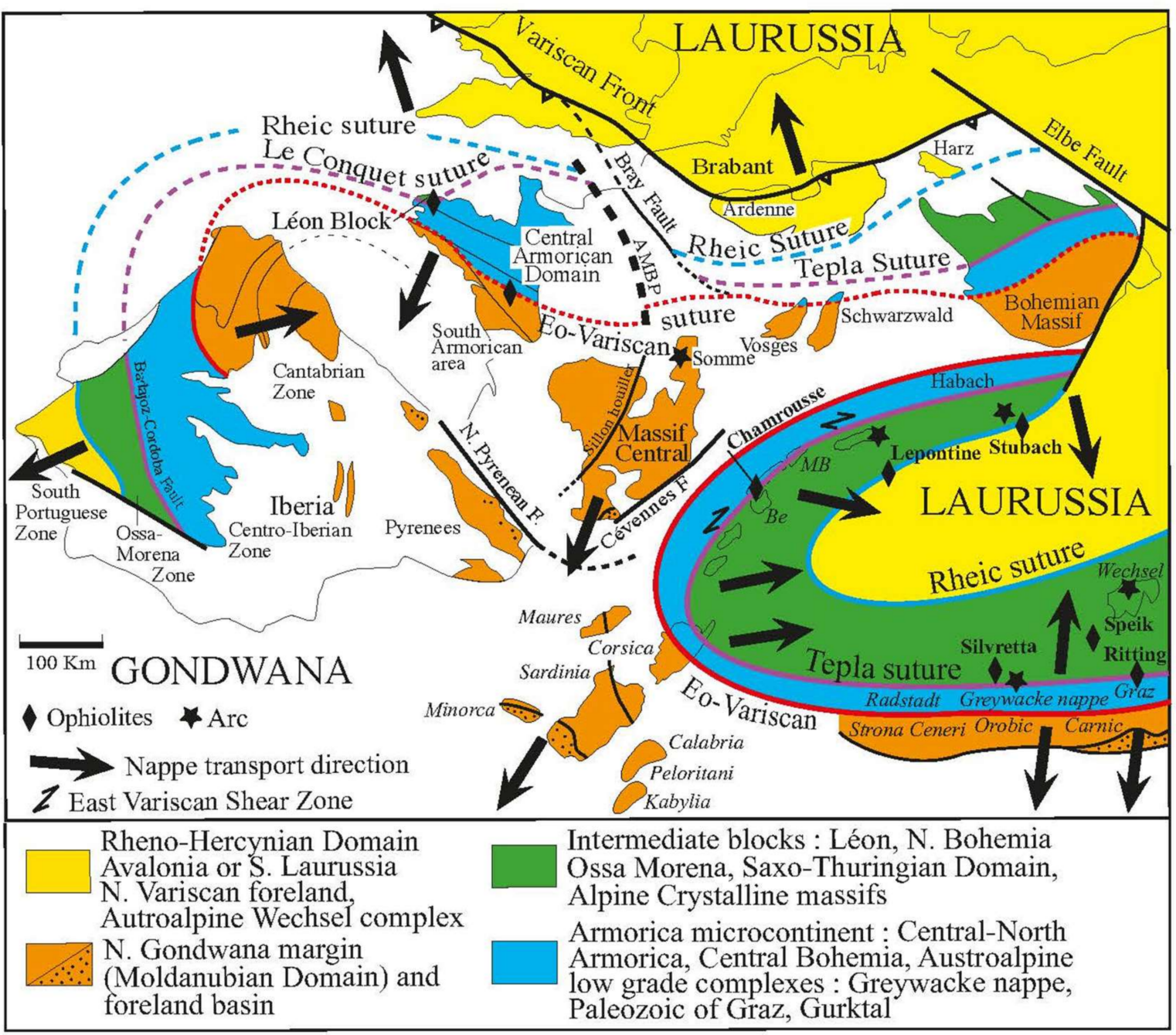

Figure 12. Palinspastic Early Permian reconstruction of the Variscan Alpidic orocline in the Western and Central Alps. The Sardinia-South Corsica-Maures and Southern Alps define the Moldanubian outer rim, including the southern foreland basins. The Western Alps External crystalline massifs, the Penninic massifs, and the unraveled Austroalpine units belong to the Armorica and Saxo-Thuringian Domains. The Alpidic orocline is cored by the Avalonian part of Laurussia. MB: Mont Blanc, Be: Belledonne.

The Southern Alps-Sardinia-South Corsica-Calabria-Peloritani-Kabylia massifs that form the outer branch of the orocline correspond to the Moldanubian Domain. The Argentella area of Corsica, the west branch of the Belledonne massif, and the low grade metamorphic units (Greywacke nappe, Paleozoic of Graz, Gurktal nappe) in the Austroalpine domain, and their underlying Cadomian basement, though not exposed everywhere, might be compared to the Armorica microcontinent. The Micaschist-marble, Koriden gneiss, and other metamorphic complexes located in the western part of the Tauern window, alike the Western Alps crystalline massifs, should be attributed to the Saxo-Thuringian block.

\section{Conclusions: A Continuous Zonation Reworked by Oroclinal Bending}

This rapid overview of the Variscan elements involved in the Alpine basement of Western, Southern, and Eastern Alps emphasizes the recognition of first-order geodynamic markers, such as ophiolites, magmatic arcs, late-orogenic foreland basins, and senses of displacement of the allochthonous units. These features allow us to propose a qualitative correlation with the Variscan domains defined in Western Europe outside the Alpine belt. 
Due to the lack of homogeneous and detailed structural, kinematic, and geochronological information in the entire belt, this palinspastic reconstruction remains preliminary.

The proposed paleogeographic scheme at the end of the Variscan orogeny, i.e., in Late Carboniferous to Early Permian times, suggests the existence of three oroclines in the Variscan belt of Western and Central Europe, namely: (i) the Ibero-Armorica (ii) the East Bohemia, and (iii) the Alpidic ones (Figures 2 and 12).

Oroclines are widespread in recent orogens (e.g., Carpathians, Western and Eastern Himalayan syntaxes, Peru-Bolivia Andes, southern Alaska, etc. ... ). The tectono-mechanical origin of these oroclines remains controversial. A discussion of the mechanisms of oroclinal bending is beyond the scope of this article. In this oroclinal view, the Western Alps crystalline massifs are ascribed to the Saxo-Thuringian Domain instead of the Moldanubian one. Such an Alpidic oroclinal bend was suggested in several reconstructions for the Western Alps [7,9] but not extended to the Eastern Alps. The Ibero-Armorica Variscan orocline site is the less disturbed, and thus the most investigated. According to paleomagnetic, structural studies, and modelling, it is argued that the bending developed during the latest stage of orogeny in Late Carboniferous to Early Permian. The Ibero-Armorica orocline is now interpreted as a secondary feature formed by buckling of an originally near-linear belt partly assisted by crustal or lithosphere-scale strike-slip faults (e.g., [158-160] and enclosed references). A similar age and formation mechanism can be assumed for the East Bohemia and Alpidic oroclines, in particular, the role of the East-Variscan shear zone $[9,10,13]$ deserves investigation, but its initial geometry has been considerably modified by the post-Variscan events. In the Devonian to Early Carboniferous, the architecture of the Variscan belt was probably more linear.

The unravelling of the Variscan fragments included in the Austroalpine nappe stack in the southern branch of the Alpidic orocline is still highly speculative as the width and kinematics of the Mesozoic oceans are controversial (e.g., [5,82,115,150,151]). The outer rim of the Alpidic orocline is rather well constrained by the consistency of the late-orogenic foreland basins from the French Montagne Noire to the Carnic Alps. Consequently, the stack of ductile and synmetamorphic units ascribed to the Moldanubian Domain is also constrained from Southern France, Sardinia-Corsica-Maures-Tanneron segment to the Serie dei Laghi, Orobic Alps, and Carnic Alps in the South Alpine Domain (Figure 12).

The correlations of the Variscan Austroalpine units with the Armorican and SaxoThuringian Domains result of the retro-translation of the Alpine nappes. The attribution of the Lepontine, and Stubach ophiolites to the Rheic ocean implies that the core of the Alpidic orocline is occupied by an Avalonian (or Laurussian) basement.

The subduction of the Western Paleotethys is sometimes invoked to account for the Variscan geodynamic evolution of the Alpine basement $[4,6]$. However, depending on the reconstructions, this ocean is located either in the South (i.e., close to Gondwana) or in the north (i.e., close to Laurussia) with respect to the Variscan orogen (e.g., $[4,6,23,125,151]$ ). Furthermore, in the study area, an Early Carboniferous subduction of the Paleotethys is not documented. In the present state of knowledge, it seems that the Paleotethys did not play any role in the building of the Variscan orogen that was already completed before the closure of the Paleotethys oceanic basin.

The basement massifs exposed in the Alpine belt are not directly representative of one given domain of the Variscan belt, as they are composite ones. Available works suggest that most of them should be subdivided on the basis of the Paleozoic ophiolitic sutures, highor low-grade metamorphic units, and foreland basins. Further improvements are required to reach a comprehensive and quantitative reconstruction. Summoning Intra-Alpine or Galatian terranes does not help to decipher the Variscan puzzle in the Alpine basement.

Author Contributions: All authors contributed to conceptualization, and writing. All authors have read and agreed to the published version of the manuscript.

Funding: This research received no external funding. 


\begin{abstract}
Acknowledgments: Claude Lepvrier and Daniel Fournier are acknowledged for their stimulating questions on the Variscan basement in the Western Alps that were the initial trigger of this study. R. Carosi is thanked for his invitation to contribute to this Special Issue. F. Neubauer and an anonymous reviewer are thanked for their constructive comments that helped us to improve the initial version of the manuscript.
\end{abstract}

Conflicts of Interest: The authors declare no conflict of interest.

\title{
References
}

1. Vai, G.B.; Cocozza, T. Tentative schematic zonation of the Hercynian chain in Italy. Bull. Soc. Geol. Fr. 1986, 8, 95-114. [CrossRef]

2. Von Raumer, J.F.; Neubauer, F. Late Precambrian and Paleozoic evolution of the Alpine basement- An overview. In The Pre-Mesozoic Geology in the Alps; von Raumer, J., Neubauer, F., Eds.; Springer: Berlin/Heidelberg, Germany, 1993; pp. 625-639.

3. Von Raumer, J.-F.; Stampfi, G.M.; Bussy, F. Gondwana-derived microcontinents, the constituents of the Variscan and Alpine collisional orogens. Tectonophysics 2003, 365, 7-22. [CrossRef]

4. Von Raumer, J.F.; Bussy, F.; Schaltegger, U.; Schulz, B.; Stampfli, G.M. Pre-Mesozoic Alpine basements? Their place in the European Paleozoic framework. GSA Bull. 2013, 125, 89-108. [CrossRef]

5. Spiess, R.; Cesare, B.; Mazzoli, C.; Sassi, R.; Sassi, F.P. The crystalline basement of the Adria microplate in the eastern Alps: A review of the palaeostructural evolution from the Neoproterozoic to the Cenozoic. Rendiconti Lincei Scienze Fisiche Naturali 2010, 21, S31-S50. [CrossRef]

6. Stampfli, G.M.; Hochard, C.; Vérard, C.; Wilhem, C.; von Raumer, J.F. The formation of Pangea. Tectonophysics 2013, 593, 1-19. [CrossRef]

7. Matte, P. The Variscan collage and orogeny (480-290 Ma) and the tectonic definition of the Armorica microplate: A review. Terra Nova 2001, 13, 122-128. [CrossRef]

8. Carosi, R.; Palmeri, R. Orogen-parallel tectonic transport in the Variscan belt of northeastern Sardinia (Italy): Implications for the exhumation of medium-pressure metamorphic rocks. Geol. Mag. 2002, 139, 497-511. [CrossRef]

9. Guillot, S.; Ménot, R.P. Paleozoic evolution of the external crystalline massifs of the Western Alps. C. R. Geosci. 2009, 341, 253-265. [CrossRef]

10. Guillot, S.; di Paola, S.; Ménot, R.P.; Ledru, P.; Spalla, M.I.; Gosso, G.; Schwartz, S. Suture zones and importance of strike-slip faulting for Variscan geodynamic reconstructions of the External Crystalline Massifs of the western Alps. Bull. Soc. Géol. Fr. 2009, 180, 483-500. [CrossRef]

11. Compagnoni, R.; Ferrando, S.; Lombardo, B.; Radulesco, N.; Rubatto, D. Paleo-European crust of the Italian Western Alps: Geological history of the Argentera Massif and comparison with Mont Blanc-Aiguilles Rouges and Maures-Tanneron Massifs. J. Virtual Explor. 2010, 36, 228. [CrossRef]

12. Padovano, M.; Elter, F.M.; Pandeli, E.; Franceschelli, M. The East Variscan Shear Zone: New insights into its role in the Late Carboniferous collision in southern Europe. Int. Geol. Rev. 2012, 54, 957-970. [CrossRef]

13. Simonetti, M.; Carosi, R.; Montomoli, C.; Cottle, J.M.; Law, R.D. Transpressive deformation in the Southern European Variscan Belt: New insights from the Aiguilles Rouges Massif (Western Alps). Tectonics 2020, 39, e2020TC006153. [CrossRef]

14. Kossmat, F. Gliederung der varistischen Gebirgsbaues. Abhandlungen des Sächsischen Geologischen Landesamts 1927, 1, 1-39.

15. Meinhold, G. Franz Kossmat-Subdivision of the Variscan Mountains-A translation of the German text with supplementary notes. Hist. Geo Space Sci. 2017, 8, 29-51. [CrossRef]

16. Matte, P. Tectonics and plate tectonics model for the Variscan belt of Europe. Tectonophysics 1986, 126, 329-374. [CrossRef]

17. Franke, W. The mid-European segment of the Variscides: Tectonostratigraphic units, terrane boundaries and plate tectonic evolution. Geol. Soc. Lond. Spec. Publ. 2000, 179, 35-61. [CrossRef]

18. Faure, M.; Bé Mézème, E.; Duguet, M.; Cartier, C.; Talbot, J.Y. Paleozoic tectonic evolution of medio-europa from the example of the French Massif Central and Massif Armoricain. J. Virtual Explor. 2005, 19, 1-25. [CrossRef]

19. Ballèvre, M.B.; Ducassou, C.; Pitra, P. Palaeozoic history of the Armorican Massif: Models for the tectonic evolution of the suture zones. C. R. Geosci. 2009, 341, 174-201. [CrossRef]

20. Martínez Catalán, J.R.; Arenas, R.; Abati, J.; Sánchez Martínez, S.; Díaz García, F.; Fernández Suárez, J.; González Cuadra, P.; Castiñeiras, P.; Gómez Barreiro, J.; Díez Montes, A.; et al. A rootless suture and the loss of the roots of a mountain chain: The Variscan belt of NW Iberia. C. R. Geosci. 2009, 341, 114-126. [CrossRef]

21. Schulmann, K.; Konopasek, J.; Janousek, V.; Lexa, O.; Lardeaux, J.M.; Edel, J.B.; Stipska, P.; Ulrich, S. An Andean type Palaeozoic convergence in the Bohemian Massif. C. R. Geosci. 2009, 341, 266-286. [CrossRef]

22. Lardeaux, J.M.; Schulmann, K.; Faure, M.; Janoucek, V.; Lexa, O.; Skrzypek, E.; Edel, J.B.; Stipska, P. The Moldanubian Zone in the French Massif Central, Vosges/ Schwarzwald and Bohemian Massif revisited: Differences and similarities. Geol. Soc. Lond. Spec. Publ. 2014, 405, 7-44. [CrossRef]

23. Edel, J.B.; Schulmann, K.; Lexa, O.; Lardeaux, J.M. Late Palaeozoic palaeomagnetic and tectonic constraints for amalgamation of Pangea supercontinent in the European Variscan belt. Earth-Sci. Rev. 2018, 177, 589-612. [CrossRef]

24. Faure, M.; Leloix, C.; Roig, J.-Y. L’Evolution polycyclique de la chaine hercynienne. Bull. Soc. Geol. Fr. 1997, 168, 695-705. 
25. Faure, M.; Bé Mézème, E.; Cocherie, A.; Rossi, P.; Chemenda, A.; Boutelier, D. Devonian geodynamic evolution of the Variscan Belt, insights from the French Massif Central and Massif Armoricain. Tectonics 2008, 27, TC2008. [CrossRef]

26. Faure, M.; Lardeaux, J.-M.; Ledru, P. A review of the pre-Permian geology of the Variscan French Massif Central. Compt. Rendus Geosci. 2009, 341, 202-213. [CrossRef]

27. Lardeaux, J.-M. Deciphering orogeny: A metamorphic perspective. Examples from European Alpine and Variscan belts-Part II: Variscan metamorphism in the French Massif Central- A review. A. Bull. Soc. Géol. Fr. 2014, 185, 281-310. [CrossRef]

28. Arthaud, F. Etude Tectonique et Microtectonique Comparée de Deux Domaines Hercyniens: Les Nappes de la Montagne Noire (France) et l'Anticlinorium de l'Iglesiente (Sardaigne); Université des Sciences et Techniques du Languedoc: Montpellier, France, $1970 ;$ p. 175.

29. Engel, W.; Feist, R.; Franke, W. Le Carbonifère anté-Stéphanien de la Montagne Noire: Rapports entre mise en place des nappes et sédimentation. Bull. Bur. De Rech. Géologiques Et Minières 1982, 2, 341-389.

30. Delvolvé, J.J.; Vachard, D.; Souquet, P. Stratigraphic record of thrust propagation, Carboniferous foreland basin, Pyrenees, with emphasis on Pays-de-Sault (France/Spain). Geologische Rundschau 1998, 87, 363-372. [CrossRef]

31. Laumonier, B. Notice explicative de la carte géologique à 1/25 000 du synclinal de Villefranche-de-Conflent entre Jujols et Nohèdes (massif du Coronat, Pyrénées-Orientales, France). Rev. Géol. Pyréenne 2016, 3, 22.

32. Edel, J.-B.; Montigny, R.; Tuizat, R. Late Paleozoic rotations of Corsica and Sardinia: New evidence from paleomagnetic and K-Ar studies. Tectonophysics 1981, 79, 201-203. [CrossRef]

33. Pin, C. Variscan oceans: Ages, origins and geodynamic implications inferred from geochemical and radiometric data. Tectonophysics 1990, 177, 215-227. [CrossRef]

34. Robardet, M. The Armorica "microplate": Fact or fiction? Critical review of the concept and contradictory palaeobiogeographical data. Palaeogeogr. Palaeoclimatol. Palaeoecol. 2003, 195, 125-148. [CrossRef]

35. Forestier, F.H. Métamorphisme Hercynien et Anté-Hercynien dans le Bassin du Haut-Allier (Massif Central Français); Thèse d'État; University Clermont-Ferrand: Clermont-Ferrand, France, 1961; p. 300.

36. Ménot, R.-P. An overview of the geology of the Belledonne Massif (external crystalline massifs of Western Alps). Schweiz. Mineral. Petrogr. Mitt. 1988, 70, 33-53.

37. Carmignani, L.; Carosi, R.; di Pisa, A. The hercynian chain in Sardinia (Italy). Geodin. Acta 1994, 7, 31-47. [CrossRef]

38. Carosi, R.; Frassi, C.; Iacopini, D.; Montomoli, C. Post collisional transpressive tectonics in northern Sardinia (Italy). J. Virtual Explor. 2005, 19, 1-30. [CrossRef]

39. Rossi, P.; Oggiano, G.; Cocherie, A. A restored section of the "southern Variscan realm" across the Corsica-Sardinia microcontinent. C. R. Geosci. 2009, 341, 224-238. [CrossRef]

40. Ballèvre, M.; Manzotti, P.; Dal Piaz, G.V. Pre-Alpine (Variscan) Inheritance: A Key for the Location of the Future Valaisan Basin (Western Alps). Tectonics 2018, 37, 786-817. [CrossRef]

41. Advokaat, E.L.; van Hinsbergen, D.J.J.; Maffione, M.; Langereis, C.G.; Vissers, R.L.M.; Cherchi, A.; Schroeder, R.; Madani, H.; Columbu, S. Eocene rotation of Sardinia, and the paleogeography of the western Mediterranean region. Earth Planet. Sci. Lett. 2014, 401, 183-195. [CrossRef]

42. Maffione, M.; Speranza, F.; Faccenna, C.; Cascella, A.; Vignaroli, G.; Sagnotti, L. A synchronous Alpine and Corsica-Sardinia rotation. J. Geophys. Res. 2008, 113, 1-25. [CrossRef]

43. Sàbat, F.; Gelabert, B.; Rodriguez-Perea, A. Minorca, an exotic Balearic island (western Mediterranean). Geol. Acta 2018, 16, 411-426. [CrossRef]

44. Rossi, P.; Cocherie, A. Genesis of a Variscan batholith: Field, mineralogical and geochemical evidence from the Corsica-Sardinia batholith. Tectonophysics 1991, 195, 319-346. [CrossRef]

45. Faure, M.; Rossi, P.; Gaché, J.; Melleton, J.; Frei, D.; Li, X.; Lin, W. Variscan orogeny in Corsica: New structural and geochronological insights, and its place in the Variscan geodynamic framework. Int. J. Earth Sci. 2014, 103, 1533-1551. [CrossRef]

46. Giacomini, F.; Dallai, L.; Carminati, E.; Tiepolo, M.; Ghezzo, C. Exhumation of a Variscan orogenic complex: Insights into the composite granulitic-amphibolitic metamorphic basement of Southeast Corsica (France). J. Metam. Geol. 2008, 26, 403-436. [CrossRef]

47. Cruciani, G.; Franceschelli, M.; Massonne, H.-J.; Carosi, R.; Montomoli, C. Pressure- temperature and deformational evolution of high-pressure metapelites from Variscan NE Sardinia, Italy. Lithos 2013, 175-176, 272-284. [CrossRef]

48. Avigad, D.; Rossi, P.; Gerdes, A.; Abbo, A. Cadomian metasediments and Ordovician sandstone from Corsica: Detrital zircon U-Pb-Hf constrains on their provenance and paleogeography. Int. J. Earth Sci. 2018, 107, 2803-2818. [CrossRef]

49. Schneider, J.; Corsini, M.; Reverso-Peil, A.; Lardeaux, J.-M. Thermal and mechanical evolution of an orogenic wedge during Variscan collision: An example in the Maures-Tanneron massif (SE France). Geol. Soc. Lond. Spec. Publ. 2014, 405, 313-331. [CrossRef]

50. Oliot, E.; Melleton, J.; Schneider, J.; Corsini, M.; Gardien, V.; Rolland, Y. Variscan crustal thickening in the Maures-Tanneron massif (South Variscan belt, France): New in situ monazite U-Th-Pb chemical dating of high-grade rocks. Bull. Soc. Geol. Fr. 2015, 186, 145-169. [CrossRef]

51. Simonetti, M.; Carosi, R.; Montomoli, C.; Corsini, M.; Petroccia, A.; Cottle, J.M.; Iaccarino, S. Timing and kinematics of flow in a transpressive dextral shear zone, Maures Massif (Southern France). Int. J. Earth Sci. 2020, 109, 2261-2285. [CrossRef] 
52. Bussy, F.; Hernandez, J.; von Raumer, J. Bimodal magmatism as a consequence of the post-collisional readjustment of the thickened Variscan continental lithosphere (Aiguilles Rouges/Mont-Blanc Massifs, western Alps). Trans. R. Soc. Edinb. Earth Sci. 2000, 91, 221-233. [CrossRef]

53. Faure-Muret, A. Etudes Géologiques Sur le Massif de l'Argentera-Mercantour; Mémoires du Service de la Carte Géologique de la France, Imprimerie Nationale: Paris, France, 1955; p. 336.

54. Bordet, P.; Bordet, C. Belledonne-Grande Rousses et Aiguilles Rouges Mont Blanc: Quelques données nouvelles sur leurs rapports structuraux. Livre à la mémoire du professeur Fallot. Mém. Hors Sér. Société Géologique Fr. 1963, 1, 309-316.

55. Carme, F. Existence de deux formations détritique remarquables dans les schistes cristallins anté-houiller du Taillefer (chaîne de Belledonne Alpes françaises). C. R. Acad. Sci. Paris 1965, 260, 6656-6659.

56. Fernandez, A.; Guillot, S.; Ménot, R.P.; Ledru, P. Late Paleozoic polyphased tectonics in the SW Belledonne massif (external crystalline massifs, French Alps). Geodin. Acta 2002, 15, 127-139. [CrossRef]

57. Fréville, K.; Trap, P.; Faure, M.; Melleton, J.; Li, X.H.; Lin, W. New structural, metamorphic and geochronological insights on the Variscan evolution of the Alpine basement in the Belledonne massif (France). Tectonophysics 2018, 146, 14-42. [CrossRef]

58. Jouffray, F.; Spalla, M.I.; Lardeaux, J.M.; Filippi, M.; Rebay, G.; Corsini, M.; Gosso, G. Variscan eclogites from the ArgenteraMercantour Massif (External Crystalline Massifs, SW Alps): A dismembered cryptic suture zone. Int. J. Earth Sci. 2020, 109, 1273-1294. [CrossRef]

59. Jacob, J.-B.; Guillot, S.; Rubato, D.; Janots, E.; Melleton, J.; Faure, M. Carboniferous high pressure metamorphism and deformation in the Belledonne Massif (Western Alps). J. Metam. Geol. 2021, 39, 1009-1044. [CrossRef]

60. Pin, C.; Carme, F. A Sm-Nd isotopic study of 500 Ma old oceanic crust in the Variscan belt of Western Europe: The Chamrousse ophiolite complex, Western Alps (France). Contrib. Miner. Pet. 1987, 96, 406-413. [CrossRef]

61. Ménot, R.-P.; Peucat, J.J.; Scarenzi, D.; Piboule, M. 496 my age of plagiogranites in the Chamrousse ophiolite complex (external crystalline massifs in the French Alps): Evidence of a Lower Paleozoic oceanization. Earth Planet. Sci. Lett. 1988, 88, 82-92. [CrossRef]

62. Dobmeier, C. Variscan P-T deformation paths from the southwestern Aiguilles Rouges massif (external massif, western Alps) and their implication for its tectonic evolution. Int. J. Earth Sci. 1998, 87, 107-123. [CrossRef]

63. Von Raumer, J.; Bussy, F. 2004. Mont Blanc and Aiguilles Rouges Geology and their polymetamorphic basement. Mémoires de Géologie 2004, 42, 204.

64. Debon, F.; Guerrot, C.; Ménot, R.-P.; Vivier, G.; Cocherie, A. Late Variscan granites in the Belledonne massif (French Western Alps): An Early Visean magnesian plutonism. Schweiz. Mineral. Und Petrogr. Mitt. 1998, 78, 67-85.

65. Genier, F.; Bussy, F.; Epard, J.L.; Baumgartner, L. Water-assisted migmatization of meta-graywackes in a Variscan shear zone, Aiguilles-Rouges massif, western Alps. Lithos 2008, 102, 575-597. [CrossRef]

66. Elter, F.M.; Musumeci, G.; Pertusati, P.C. Late Hercynian shear zones in Sardinia. Tectonophysics 1990, 176, 387-404. [CrossRef]

67. Corsini, M.; Rolland, Y. Late evolution of the southern European Variscan Belt: Exhumation of the lower crust in a context of oblique convergence. C. R. Geosci. 2009, 341, 214-223. [CrossRef]

68. Carosi, R.; Montomoli, C.; Tiepolo, M.; Frassi, C. Geochronological constraints on post-collisional shear zones in the Variscides of Sardinia (Italy). Terra Nova 2012, 24, 42-51. [CrossRef]

69. Carosi, R.; Petroccia, A.; Iaccarino, S.; Simonetti, M.; Langone, A.; Montomoli, C. Kinematics and Timing Constraints in a Transpressive Tectonic Regime: The Example of the Posada-Asinara Shear Zone (NE Sardinia, Italy). Geosciences 2020, 10, 288. [CrossRef]

70. Choukroune, P.; Ballèvre, M.; Cobbold, P.; Gautier, Y.; Merle, O.; Vuichard, J.P. Deformation and motion in the western Alpine arc Tectonics 1986, 5, 215-226. [CrossRef]

71. Manzotti, P.; Ballèvre, M.; Poujol, M. Detrital zircon geochronology in the Dora Maira and Zone Houillère: A record of sediment travel paths in the Carboniferous. Terra Nova 2016, 28, 279-288. [CrossRef]

72. Desmons, J.; Compagnoni, R.; Cortesogno, L.; Frey, M.; Gaggero, L. Pre-Alpine metamorphism of the internal zone of the Western Alps. Schweiz. Mineral. Und Petrogr. Mitt. 1999, 79, 23-39.

73. Marotta, A.M.; Spalla, M.I. Permian-Triassic high thermal regime in the Alps: Result of Late Variscan collapse or continental rifting? Validation by numerical modeling. Tectonics 2007. [CrossRef]

74. Spalla, M.I.; Zanoni, D.; Marotta, A.M.; Rebay, G.; Roda, M.; Zucali, M.; Gosso, G. The transition from Variscan collision to continental break-up in the Alps: Insights from the comparison between natural data and numerical model predictions. Geol. Soc. Lond. Spec. Publ. 2014, 405, 363-400. [CrossRef]

75. Regorda, A.; Lardeaux, J.M.; Roda, M.; Marotta, A.M.; Spalla, M.I. How many subductions in the Variscan orogeny? Insights from numerical models. Geosci. Front. 2020, 11, 1025-1052. [CrossRef]

76. Monié, P. Preservation of Hercynian 40Ar/39Ar ages through high-pressure low temperature Alpine metamorphism in the Western Alps. Eur. J. Mineral. 1990, 2, 343-361. [CrossRef]

77. Guillot, F.; Schaltegger, U.; Bertrand, J.-M.; Deloule, E.; Baudin, T. Zircon U-Pb geochronology of Ordovician magmatism in the polycyiclic Ruitor Massif (Internal W-Alps). Int. J. Earth Sci. 2002, 91, 964-978. [CrossRef]

78. Giacomini, F.; Braga, R.; Tiepolo, M.; Tribuzio, R. New constraints on the origin and age of Variscan eclogitic rocks (Ligurian Alps, Italy). Contrib. Miner. Pet. 2007, 153, 29-53. [CrossRef] 
79. Maino, M.; Gaggero, L.; Langone, A.; Seno, S.; Fanning, M. Cambro-Silurian magmatisms at the northern Gondwana margin (Penninic basement of the Ligurian Alps). Geosci. Front. 2019, 10, 315-330. [CrossRef]

80. Pfeiffer, H.R.; Biino, G.; Ménot, R.P.; Stille, P. Ultramafic rocks in the pre-Mesozoic basement of the Central and External Western Alps. In The Pre-Mesozoic Geology in the Alps; von Raumer, J., Neubauer, F., Eds.; Springer: Berlin/Heidelberg, Germany, 1993; pp. 119-143.

81. Schaltegger, U.; Gebauer, D.; von Quadt, A. The mafic-ultramafic rock association of Loderio-Biasca (lower Pennine nappes, Ticino, Switzerland): Cambrian oceanic magmatism and its bearing on early Paleozoic paleogeography. Chem. Geol. 2002, 186, 265-279. [CrossRef]

82. Schmid, S.M.; Fugenschuh, B.; Kissling, E.; Schuster, R. Tectonic map and overall architecture of the Alpine orogen. Eclogae Geol. Helv. 2004, 97, 93-117. [CrossRef]

83. Eichhorn, R.; Loth, G.; Höll, R.; Finger, F.; Schermaier, A.; Kennedy, A. Multistage variscan magmatism in the central Tauern Window (Austria) unveiled by U/Pb SHRIMP zircon data. Contrib. Mineral. Petrol. 2000, 139, 418-435. [CrossRef]

84. Eichhorn, R.; Loth, G.; Kennedy, A. Unravelling the pre-Variscan evolution of the Habach terrane (Tauern Window, Austria) by U-Pb SHRIMP zircon data. Contrib. Mineral. Petrol. 2001, 142, 147-162. [CrossRef]

85. Kozlik, M.; Raitha, J.G.; Gerdes, A. U-Pb, Lu-Hf and trace element characteristics of zircon from the Felbertal scheelite deposit (Austria): New constraints on timing and source of W mineralization. Chem. Geol. 2016, 421, 112-126. [CrossRef]

86. Vavra, G.; Frisch, W. 1989. Pre-Variscan back-arc and island-arc magmatism in the Tauern window (Eastern Alps). Tectonophysics 1989, 169, 271-280. [CrossRef]

87. Poli, M.E.; Zanferrari, A. The Agordo basement (NE Italy): A 500 Ma-long geological record in the Southalpine crust, IGCP No. 276. In Contributions to the Geology of Italy with Special Regards to the Paleozoic Basements; Carmignani, L., Sassi, F.P., Eds.; Newsletter: Siena, Italy, 1992; pp. 283-296.

88. Castellarin, A.; Selli, L.; Picotti, V.; Cantelli, L. La tettonica delle Dolomiti nelle quadro delle Alpi Meridionali. Mem. Della Soc. Geol. Ital. 1998, 53, 133-143.

89. Zanchetta, S.; Malusà, G.M.; Zanchi, A. Precollisional development and Cenozoic evolution of the Southalpine retrobelt (European Alps). Lithosphere 2015, 7, 662-681. [CrossRef]

90. Cassinis, G.; Perotti, C.R.; Ronchi, A. Permian continental basins in the Southern Alps (Italy) and peri-mediterranean correlations. Int. J. Earth Sci. Geol. 2012, 101, 129-157. [CrossRef]

91. Giobbi Origoni, E.; Gregnanin, A. The crystalline basement of the "Massiccio delle Tre Valli Bresciane": New petrographic and chemical data. Mem. Soc. Geol. It. 1983, 26, 133-144.

92. Mottana, A.; Nicoletti, M.; Petrucciani, G.; Liborio, G.; De Capitani, L.; Bocchio, R. Pre-Alpine and Alpine evolution of the Southalpine basement of the Orobic Alps. Geol. Rundsch. 1985, 74, 353-366. [CrossRef]

93. Gansser, A.; Pantic, N. Prealpine events along the Eastern Insubric Line (Tonale Line, northern Italy). Eclogae Geol. Helv. 1988, 81, 567-577.

94. Milano, P.F.; Pennacchioni, G.; Spalla, M.I. Alpine and pre-Alpine tectonics in the Central Orobic Alps (Southern Alps). Eclogae Geol. Helv. 1988, 81, 273-293.

95. Diella, V.; Spalla, M.I.; Tunesi, A. Contrasted thermo-mechanical evolutions in the Southalpine metamorphic basement of the Orobic Alps (Central Alps, Italy). J. Metamorph. Geol. 1992, 10, 203-219. [CrossRef]

96. Siletto, G.B.; Spalla, M.I.; Tunesi, A.; Lardeaux, J.M.; Colombo, A. Pre-Alpine structural and metamorphic histories in the Orobic Southern Alps, Italy. In The Pre-Mesozoic Geology in the Alps; von Raumer, J., Neubauer, F., Eds.; Springer: Berlin/Heidelberg, Germany, 1993; pp. 583-596.

97. Gosso, G.; Siletto, G.B.; Spalla, M.I. International ophiolite symposium field excursion guide-Continental rifting to ocean floor metamorphism (21st-23rd September 1995): First day: H-T/L-P metamorphism and structures in the South-Alpine basement near Lake Como, Orobic Alps; intracontinental imprints of the Permo-Triassic rifting. Ofioliti 1997, 22, $133-145$.

98. Spalla, M.I.; Gosso, G. Pre-Alpine tectonometamorphic units in the central Southern Alps: Structural and metamorphic memory. Mem. Sci. Geol. 1999, 51, 221-229.

99. Spalla, M.I.; Siletto, G.B.; di Paola, S.; Gosso, G. The role of structural and metamorphic memory in the distinction of tectonometamorphic units: The basement of the Como lake in the Southern Alps. J. Geodyn. 2000, 30, 191-204. [CrossRef]

100. Spalla, M.I.; Zanoni, D.; Gosso, G.; Zucali, M. Deciphering the geologic memory of a Permian conglomerate of the Southern Alps by pebble P-T estimates. Int. J. Earth Sci. 2009, 98, 203-226. [CrossRef]

101. Zanoni, D.; Spalla, M.I.; Gosso, G. Vestiges of lost tectonic units in conglomerate pebbles? A test in Permian sequences of the Southalpine Orobic Alps. Geol. Mag. 2010, 147, 98-122. [CrossRef]

102. Boriani, A.; Giobbi Origoni, E.; Borghi, A.; Caironi, V. The evolution of the Serie dei Laghi (Strona-Ceneri and Scisti dei Laghi): The upper component of the Ivrea-Verbano crustal section; Southern Alps, North Italy and Ticino, Switzerland. Tectonophysics 1990, 182, 103-118. [CrossRef]

103. Giobbi Origoni, E.; Zappone, A.; Boriani, A.; Bocchio, R.; Morten, L. Relics of pre-Alpine ophiolites in the Serie dei Laghi (Western Southern Alps). Schweiz. Mineral. Petrogr. Mitt. 1997, 77, 187-207.

104. Franz, L.; Romer, R.L. Caledonian high-pressure metamorphism in the Strona-Ceneri Zone (Southern Alps of southern Switzerland and northern Italy). Swiss J. Geosci. 2007, 100, 457-467. [CrossRef] 
105. Spalla, M.I.; Gosso, G.; Marotta, A.M.; Zucali, M.; Salvi, F. Analysis of natural tectonic systems coupled with numerical modelling of the polycyclic continental lithosphere of the Alps. Int. Geol. Rev. 2010, 52, 1268-1302. [CrossRef]

106. Ring, U.; Richter, C. 1994. The Variscan structural and metamorphic evolution of the eastern Southalpine basement. J. Geol. Soc. Lond. 1994, 151, 755-766. [CrossRef]

107. Hammerschmidt, K.; Stöckhert, B. A K-Ar and ${ }^{40} \mathrm{Ar} /{ }^{39} \mathrm{Ar}$ study on white micas from the Brixen Quartzophyllite, southern Alps. Evidence for argon loss at low temperatures. Contrib. Mineral. Petrol. 1987, 95, 393-406. [CrossRef]

108. Schönlaub, H.P.; Histon, K. The Palaeozoic evolution of the Southern Alps. Mitt. Österr. Geol. Ges. 2000, 92, 15-34.

109. Pondrelli, M.; Corradini, C.; Simonetto, L.; Corriga, M.G.; Kido, E.; Mossoni, A.; Spalletta, C.; Suttner, T.J.; Carta, N. Depositional evolution of a lower Paleozoic portion of the Southalpine domain: The Mt. Pizzul area (Carnic Alps, Italy). Int. J. Earth Sci. 2014, 104, 147-178. [CrossRef]

110. Venturini, C. Field Workshop on Carboniferous to Permian Sequence of the Pramollo-Nassfeld Basin (Carnic Alps), 2-8 September 1990; Mus. Friulano Sci. Nat.: Udine, Italy, 1990; pp. 1-159.

111. Spalletta, C.; Venturini, C. Late Devonian-early Carboniferous synsedimentary tectonic evolution of the Palaeocarnic domain (Southern Alps, Italy). Giorn. Geol. 1995, 56, 211-222.

112. Läufer, A.L.; Hubich, D.H.; Loeschke, J.L. 2001. Variscan geodynamic evolution of the Carnic Alps (Austria/Italy). Int. J. Earth Sci. 2001, 90, 855-870.

113. Vachard, D.; Izart, A.; Cózar, P. Mississippian (middle Tournaisian-late Serpukhovian) lithostratigraphic and tectonosedimentary units of the southeastern Montagne Noire (Hérault, France). Géologie de la France 2017, 1, 47-88.

114. Alabouvette, B.; Demange, M.; Guérangé-Lozes, J.; Ambert, P. Notice Explicative de la Carte Géologique au 1:250000 de Montpellier; Bureau de Recherches Géologiques et Minières: Orléans, France, 2003.

115. Kurz, W.; Fritz, H. Tectonometamorphic evolution of the Austroalpine Nappe Complex in the Central Eastern Alps consequences for the Eo-Alpine evolution of the Eastern Alps. Int. Geol. Rev. 2003, 45, 1100-1127. [CrossRef]

116. Schuster, R.; Koller, F.; Hoeck, V.; Hoinkes, G.; Bousquet, R. Explanatory notes to the map: Metamorphic structure of the Alps-metamorphic evolution of the Eastern Alps. Mitt. Der Österr. Mineral. Ges. 2004, 149, 175-199.

117. Schulz, B.; Bombach, K.; Pawlig, S.; Braetz, H. Neoproterozoic to early-Palaeozoic magmatic evolution in the Gondwana-derived Austroalpine basement to the south of the Tauern Window (eastern Alps). Int. J. Earth Sci. 2004, 93, 824-843. [CrossRef]

118. Neubauer, F.; Frisch, W. The Austroalpine metamorphic basement east of the Tauern Window. In The Pre-Mesozoic Geology in the Alps; von Raumer, J., Neubauer, F., Eds.; Springer: Berlin/Heidelberg, Germany, 1993; pp. 515-536.

119. Neubauer, F.; Frisch, W.; Schmerold, R.; Schlöser, M. Metamorphosed and dismembered ophiolite suites in the basement units of the Eastern Alps. Tectonophysics 1989, 164, 49-62. [CrossRef]

120. Neubauer, F.; Hoinkes, G.; Sassi, F.P.; Handler, R.; Höck, V.; Koller, F.; Frank, W. Pre-Alpine metamorphism of the Eastern Alps. Schweiz. Mineral. Petrogr. Mitt. 1999, 79, 41-62.

121. Frisch, W.; Ménot, R.P.; Neubauer, F.; von Raumer, J.F. Correlation and volution of the Alpine basement. Schweiz. Mineral. Petrogr Mitt. 1990, 70, 265-285.

122. Neubauer, F.; Frisch, W.; Hensen, B.T. Early Palaeozoic tectonothermal events in basement complexes of the Eastern Greywacke zone (eastern Alps): Evidence from U-Pb zircon data. Int. J. Earth Sci. 2002, 91, 775-786. [CrossRef]

123. Faryad, S.W.; Melcher, F.; Hoinkes, G.; Puhl, J.; Meisel, T.; Frank, W. Relics of eclogite facies metamorphism in the Austroalpine basement, Hochgrössen (Speik complex), Austria. Miner. Pet. 2002, 74, 49-73.

124. Melcher, F.; Meisel, T. A metamorphosed early Cambrian crust-mantle transition in the Eastern Alps. J. Petrol. 2004, 45, 1689-1723. [CrossRef]

125. Chang, R.H.; Neubauer, F.; Liu, Y.J.; Yuan, S.H.; Genser, J.; Huang, Q.W.; Guan, Q.B.; Yi, S.Y. Hf isotopic constraints for the Austroalpine basement evolution of Eastern Alps: Review and new data. Earth Sci. Rev. 2021, 221, 103772. [CrossRef]

126. Stüwe, K.; Schuster, R. Initiation of subduction in the Alps: Continent or ocean? Geology 2010, 38, 175-178. [CrossRef]

127. Schorn, S.; Stüwe, K. The Plankogel detachment of the Eastern Alps: Petrological evidence for an orogen-scale extraction fault. J. Metam. Geol. 2016, 34, 147-166. [CrossRef]

128. Herg, A.; Stüwe, K. Tectonic interpretation of the metamorphic field gradient south of the Koralpe in the Eastern Alps. Austrian J. Earth Sci. 2018, 111, 155-170. [CrossRef]

129. Neubauer, F.; Sassi, F.P. The Austroalpine Quartzphyllites and related Paleozoic formation. In The Pre-Mesozoic Geology in the Alps; von Raumer, J., Neubauer, F., Eds.; Springer: Berlin/Heidelberg, Germany, 1993; pp. 423-439.

130. Fritz, H.; Neubauer, F. Geodynamic aspects of the Silurian and Early Devonian sedimentation in the Paleozoic of Graz (Eastern Alps). Schweiz. Mineral. Petrogr. Mitt. 1988, 68, 359-367.

131. Gasser, D.; Stüwe, K.; Fritz, H. Internal structural geology of the Paleozoic of Graz. Int. J. Earth Sci. 2010, 99, 1067-1081. [CrossRef]

132. Handler, R.; Dallmeyer, R.D.; Neubauer, F.; Hermann, S. ${ }^{40} \mathrm{Ar} /{ }^{39} \mathrm{Ar}$ mineral ages from the Kaintaleck nappe, Austroalpine basement, Eastern Alps. Geol. Carpath. 1999, 50, 229-239.

133. Becker, L.P. Erläuterungen zu Blatt 162 Köflach. Geologische Karte der Republik Österreich 1: 50.000; Geologische, Bundesanstalt: Wien, Austria, 1979.

134. Mandl, M.; Kurz, W.; Hauzenberger, C.; Fritz, H.; Klötzli, U.; Schuster, R. Pre-Alpine evolution of the Seckau Complex (Austroalpine basement/Eastern Alps): Constraints from in-situ LA-ICP-MS U/Pb zircon geochronology. Lithos 2018, 296-299, 412-430. [CrossRef] 
135. Yuan, S.-H.; Neubauer, F.; Liu, Y.-J.; Genser, J.; Liu, B.; Yu, S.-Y.; Chang, R.-H.; Guan, Q.-B. Widespread Permian granite magmatism in Lower Austroalpine units: Significance for Permian rifting in the Eastern Alps. Swiss J. Geosci. 2020, 113, 18. [CrossRef]

136. Neubauer, F.; Liu, Y.-J.; Chang, R.-H.; Yuan, S.-H.; Yu, S.-Y.; Genser, J.; Liu, B.; Guan, Q.-B. The Wechsel Gneiss Complex of Eastern Alps: An Ediacaran to Cambrian continental arc and its Early Proterozoic hinterland. Swiss J. Geosci. 2020, 113, 21. [CrossRef]

137. Müller, W.; Dallmeyer, R.D.; Neubauer, F.; Thöni, M. Deformation-induced resetting of Rb/Sr and ${ }^{40} \mathrm{Ar} /{ }^{40} \mathrm{Ar}$ mineral systems in a low-grade, polymetamorphic terrane (eastern Alps, Austria). J. Geol. Soc. Lond. 1999, 156, 261-278. [CrossRef]

138. Schaltegger, U.; Nägler, T.N.; Corfu, F.; Maggetti, M.; Galetti, G.; Stosch, H. A Cambrian island arc in the Silvretta nappe: Constraints from geochemistry and geochronology. Schweiz. Mineral. Und Petrogr. Mitt. 1997, 77, 337-350.

139. Müller, B.; Klötzli, U.; Schaltegger, U.; Flisch, M. Early Cambrian oceanic plagiogranite in the Silvretta Nappe, eastern Alps: Geochemical, zircon $\mathrm{U} / \mathrm{Pb}$ and $\mathrm{Rb}-\mathrm{Sr}$ data from garnet-hornblende-plagioclase gneisses. Geol. Rundsch. 1996, 85, 822-831. [CrossRef]

140. Maggetti, M.; Flisch, M. Evolution of the Silvretta nappe. In The Pre-Mesozoic Geology in the Alps; von Raumer, J., Neubauer, F., Eds.; Springer: Berlin/Heidelberg, Germany, 1993; pp. 469-484.

141. Müller, B.; Klötzli, U.; Flisch, M. U-Pb and Pb-Pb zircon dating of the older orthogneiss suite in the Silvretta nappe, eastern Alps: Cadomian magmatism in the upper Austro-Alpine realm. Geol. Rundsch. 1995, 84, 457-465. [CrossRef]

142. Poller, U. 1997. U/Pb single zircon study of gabbroic and granitic rocks of Val Barlas (Silvretta nappe, Switzerland). Schweiz. Mineral. Petrogr. Mitt. 1997, 77, 351-359.

143. Neubauer, F. Evolution of late Neoproterozoic to early Paleozoic tectonic elements in central and southeast European Alpine mountain belts: Review and synthesis. Tectonophysics 2002, 352, 87-103. [CrossRef]

144. Schulz, B.; Steenken, A.; Siegesmund, S. Geodynamic evolution of an Alpine terrane-The Austroalpine basement to the south of the Tauern Window as a part of the Adriatic plate (eastern Alps), in Tectonic Aspects of the Alpine-Dinaride-Carpathian System. Geol. Soc. Lond. Spec. Publ. 2008, 298, 5-44. [CrossRef]

145. Siegesmund, S.; Oriolo, S.; Heinrichs, T.; Basei, M.A.S.; Nolte, N.; Hüttenrauch, F.; Schulz, B. Provenance of Austroalpine basement metasediments: Tightening up Early Palaeozoic connections between peri-Gondwanan domains of central Europe and Northern Africa. Int. J. Earth Sci. 2018, 107, 2293-2315. [CrossRef]

146. Neubauer, F. The Variscan orogeny in the Austroalpine and Southalpine domains of the eastern Alps. Schweiz. Mineral. Petrogr. Mitt. 1988, 68, 339-349.

147. Leloup, P.H.; Arnaud, N.; Sobel, E.R.; Lacassin, R. Alpine thermal and structural evolution of the highest external crystalline massif: Exhumation of the Mont-Blanc massif. Tectonics 2005, 24, TC4002. [CrossRef]

148. Collombet, M.; Thomas, J.C.; Chauvin, A.; Tricart, P.; Bouillin, J.P.; Gratier, J.P. Counterclockwise rotation of the western Alps since the Oligocene: New insights from paleomagnetic data: Tertiary rotation of the Western Alps. Tectonics 2002, 21. [CrossRef]

149. Thomas, J.C.; Claudel, M.E.; Collombet, M.; Tricart, P.; Chauvin, A.; Dumont, T. First paleomagnetic data from the sedimentary cover of the French Penninic Alps: Evidence for Tertiary counterclockwise rotations in the Western Alps. Earth Planet. Sci. Lett. 1999, 171, 561-574. [CrossRef]

150. Schmid, S.M.; Kissling, E. The arc of the western Alps in the light of geophysical data on deep crustal structure. Tectonics 2000, 19, 62-85. [CrossRef]

151. Van Hinsbergen, D.J.J.; Torsvik, T.H.; Schmid, S.; Matenco, L.C.; Maffione, M.; Vissers, R.L.M.; Gürer, D.; Spakman, W. Orogenic architecture of the Mediterranean region and kinematic reconstruction of its tectonic evolution since the Triassic. Gondwana Res. 2020, 81, 79-229. [CrossRef]

152. Neubauer, F.; Liu, Y.; Dong, Y.; Chang, R.; Genser, J.; Yuan, S. Pre-Alpine tectonic evolution of the Eastern Alps: From Prototethys to Paleotethys. Earth Sci. Rev. 2022, in press. [CrossRef]

153. Krstekanić, N.; Matenco, L.; Toljić, M.; Mandić, O.; Stojadinović, U.; Willingshofer, E. Understanding partitioning of deformation in highly arcuate orogenic systems: Inferences from the evolution of the Serbian Carpathians. Glob. Planet. Change 2020, 195, 103361. [CrossRef]

154. Krstekanić, N.; Matenco, L.; Stojadinovic, U.; Willingshofer, E.; Toljić, M.; Tamminga, D. Strain partitioning in a large intracontinental strike-slip system accommodating backarc-convex orocline formation: The Circum-Moesian Fault System of the Carpatho-Balkanides. Glob. Planet. Change 2022, 206, 103714. [CrossRef]

155. Arthaud, F.; Matte, P. Late Paleozoic strike-slip faulting in southern Europe and northern Africa: Result of a right-lateral shear zone between the Appalachians and the Urals. Bull. Geol. Soc. Am. 1977, 88, 1305-1320. [CrossRef]

156. Muttoni, G.; Kent, D.V.; Garzanti, E.; Brack, P.; Abrahamsen, N.; Gaetani, M. Early Permian Pangea 'B' to Late Permian Pangea 'A'. Earth Planet. Sci. Lett. 2003, 215, 379-394. [CrossRef]

157. Muttoni, G.; Kent, D.V. Adria as promontory of Africa and its conceptual role in the Tethys twist and Pangea A to Pangea B transformation in the Permian. Riv. Ital. Paleont. Strat. 2019, 125, 249-269.

158. Gutiérrez-Alonso, G.; Fernandez-Suarez, J.; Jeffries, T.E.; Johnston, S.T.; Pastor-Galan, D.; Murphy, J.B.; Franco, M.P.; Gonzalo, J.C. Diachronous post-orogenic magmatism within a developing orocline in Iberia, European Variscides. Tectonics 2011, 30 , TC5008. [CrossRef] 
159. Weil, A.B.; Gutiérrez-Alonso, G.; Johnston, S.T.; Pastor-Galan, D. Kinematic constraints on buckling a lithosphere-scale orocline along the northern margin of Gondwana: A geologic synthesis. Tectonophysics 2013, 582, 25-49. [CrossRef]

160. Pastor-Galán, D.; Pueyo, E.L.; Diederen, M.; García-Lasanta, C.; Langereis, C.G. Late Paleozoic Iberian orocline(s) and the missing shortening in the core of Pangea. Paleo-magnetism from the Iberian Range. Tectonics 2018, 37, 3877-3892. [CrossRef] 